\title{
Sex Differences in Otolaryngology: Focus on the Emerging Role of Estrogens in Inflammatory and Pro-Resolving Responses
}

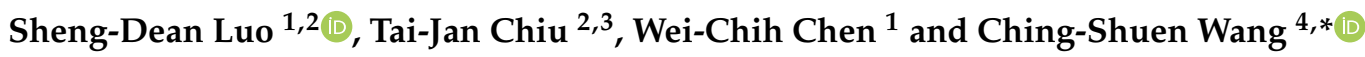 \\ 1 Department of Otolaryngology, Kaohsiung Chang Gung Memorial Hospital and Chang Gung University \\ College of Medicine, Kaohsiung 833, Taiwan; rsd0323@cgmh.org.tw (S.-D.L.); \\ jarva@adm.cgmh.org.tw (W.-C.C.) \\ 2 Graduate Institute of Clinical Medical Sciences, College of Medicine, Chang Gung University, \\ Taoyuan 333, Taiwan; kuerten@cgmh.org.tw \\ 3 Department of Hematology-Oncology, Kaohsiung Chang Gung Memorial Hospital and Chang Gung \\ University College of Medicine, Kaohsiung 833, Taiwan \\ 4 School of Dentistry, College of Oral Medicine, Taipei Medical University, Taipei 110, Taiwan \\ * Correspondence: chingshuenwang@tmu.edu.tw; Tel.: +886-227-361-661 (ext. 5166)
}

Citation: Luo, S.-D.; Chiu, T.-J.; Chen, W.-C.; Wang, C.-S. Sex Differences in Otolaryngology: Focus on the Emerging Role of Estrogens in Inflammatory and Pro-Resolving Responses. Int. J. Mol. Sci. 2021, 22, 8768. https://doi.org/10.3390/ ijms22168768

Academic Editor: Hong-Yo Kang

Received: 27 June 2021

Accepted: 13 August 2021

Published: 16 August 2021

Publisher's Note: MDPI stays neutral with regard to jurisdictional claims in published maps and institutional affiliations.

Copyright: (c) 2021 by the authors. Licensee MDPI, Basel, Switzerland. This article is an open access article distributed under the terms and conditions of the Creative Commons Attribution (CC BY) license (https:// creativecommons.org/licenses/by/ $4.0 /)$.

\begin{abstract}
Otolaryngology (also known as ear, nose, and throat (ENT)) diseases can be significantly affected by the level of sex hormones, which indicates that sex differences affect the manifestation, pathophysiology, and outcomes of these diseases. Recently, increasing evidence has suggested that proinflammatory responses in ENT diseases are linked to the level of sex hormones. The sex hormone receptors are present on a wide variety of immune cells; therefore, it is evident that they play crucial roles in regulating the immune system and hence affect the disease progression of ENT diseases. In this review, we focus on how sex hormones, particularly estrogens, regulate ENT diseases, such as chronic rhinosinusitis, vocal fold polyps, thyroid cancer, Sjögren's syndrome, and head and neck cancers, from the perspectives of inflammatory responses and specialized proresolving mediatordriven resolution. This paper aims to clarify why considering sex differences in the field of basic and medical research on otolaryngology is a key component to successful therapy for both males and females in the future.
\end{abstract}

Keywords: sex hormone; ENT diseases; estrogens; resolution of inflammation; resolvins; specialized lipid mediators; sex difference; otolaryngology; lipoxins; formyl peptide receptor 2

\section{Introduction}

Ear, nose, and throat (ENT) diseases are referred to as diseases of the ear, nose, and throat, as well as those related to the head and neck structures. Examples include chronic rhinosinusitis (CRS), vocal fold polyps, hearing loss, smell and taste disorders, Sjögren's syndrome (SS), and head and neck cancers (HNCs) [1-9]. ENT diseases significantly affect the everyday life of those afflicted, because they affect their ability to hear, smell, or speak properly. However, most ENT diseases are often overlooked because the patients are also found to be suffering from other comorbid conditions, such as autoimmune diseases, cardiovascular diseases, diabetes, and dementia [10-17]. These comorbidities show significant differences between males and females, implicating that sex plays an important role in the progression of ENT diseases.

Sex differences include differences in sex hormones and their effects on organ systems. In fact, sex hormones can positively or negatively affect the immune system [18-23]. Males predominantly produce testosterone from the testes, whereas small amounts of estrogens and progesterone are produced by other organs, such as the adrenal glands and peripheral tissues. In contrast, females predominantly produce estrogens and progesterone from the ovaries, whereas little testosterone is produced from the adrenal glands [23,24]. Testosterone plays important roles in regulating immune cells, such as T-helper 1 (Th1) and 
natural killer cells [25]. Estrogens induce T-cell homing through up-regulation of the C-C chemokine receptor type 5 expression [26]. These findings indicate that sex hormones influence the immune system and result in some immune responses being sexually dimorphic, which eventually determines the fate of the disease progression $[19,20,22,23]$.

Most ENT diseases are associated with chronic inflammatory conditions in which the endogenous mechanism to restore tissue homeostasis is altered. Therefore, an appropriate approach to prevent or ameliorate ENT disease progression should involve the activation of the resolution pathway of the inflammatory process. The resolution of inflammation is a highly controlled and coordinated process that is mediated by specialized pro-resolving mediators (SPMs), such as resolvins and lipoxins $[27,28]$. SPMs are biosynthesized from $\omega-3$ or $\omega-6$ by 5 -lipoxygenase $[29,30]$. These SPMs modulate immune activities, such as the infiltration of immune cells, removal of apoptotic cell debris, and inhibition of the synthesis of proinflammatory cytokines $[29,30]$. Recently, several studies have demonstrated the critical connection between sex hormones and specialized pro-resolving mediators, implying a significant difference between sexes in terms of disease progression and outcome [31-33]. For example, some studies demonstrated that SPMs, such as resolvins and lipoxins, can resolve uncontrolled inflammation and maintain tissue homeostasis in ENT diseases [34-37]. As the ENTs are chronic inflammatory diseases and their rate of occurrence and severity differs between sexes, in this review, we present the current understanding of sex differences in the relationship between the SPM-dependent resolution of inflammation and outcomes of ENT diseases. Despite the growing significance of the effect of sex hormones on the immune system in ENT disease progression, it has rarely been characterized.

Studies that investigate the effect of sex hormones, such as testosterone or progesterone, on the immune system are more limited compared to those that examine the effects of estrogens. Therefore, this paper summarizes the sex differences, relating mostly to estrogens, in ENT diseases. We also summarize the recent advances made in clarifying the effect of estrogens in some ENT diseases from the perspectives of inflammatory responses and specialized pro-resolving mediator-driven resolution (Table 1), and discuss the underlying immunological mechanisms that can regulate the progression and outcome of these diseases. 
Table 1. Sex difference in ENT diseases from the perspectives of inflammatory responses and specialized proresolving mediator-driven resolution.

\begin{tabular}{|c|c|c|c|c|c|c|c|}
\hline ENT Diseases & Sex Bias & $\begin{array}{l}\text { Level of } \\
\text { Estrogens }\end{array}$ & $\begin{array}{l}\text { Sex Hormone } \\
\text { Receptors }\end{array}$ & $\begin{array}{l}\text { Cells Involved in } \\
\text { the Pathogenesis }\end{array}$ & $\begin{array}{l}\text { Cytokines Involved } \\
\text { in the Pathogenesis }\end{array}$ & $\begin{array}{l}\text { Involvement of Resolution } \\
\text { of Inflammation Factors }\end{array}$ & References \\
\hline $\begin{array}{l}\text { Chronic } \\
\text { rhinosinusitis with } \\
\text { nasal polyps }\end{array}$ & $\begin{array}{l}\text { 1. Male } \\
\text { 2. Female with lower } \\
\text { estrogens }\end{array}$ & Low estrogens & High ER $\alpha$ & $\begin{array}{l}\text { 1. Th2, eosinophile } \\
\text { 2. Epithelial cells } \\
\text { 3. Macrophages }\end{array}$ & $\begin{array}{l}\text { IL-4, IL-5, IL-13, } \\
\text { IL-25, IL-33 }\end{array}$ & $\begin{array}{l}\text { 1. Intake of omega-3 fatty acid } \\
\text { show delaying incidence } \\
\text { of recurrence } \\
\text { 2. Alteration of RvD2, LXA4, } \\
\text { RvD1, LTD4, LTE4, PGD2, and } \\
\text { 11 } \beta \text { PGF2 } \alpha \text { profile }\end{array}$ & \multirow[t]{2}{*}{ [38-71] } \\
\hline $\begin{array}{l}\text { Chronic } \\
\text { rhinosinusitis } \\
\text { without } \\
\text { nasal polyps }\end{array}$ & Female & $\mathrm{N} / \mathrm{A}$ & $\mathrm{N} / \mathrm{A}$ & $\begin{array}{l}\text { 1. Th1 cells } \\
\text { 2. Neutrophil } \\
\text { 3. DC }\end{array}$ & $\begin{array}{c}\text { IFN, IL-6, IL-8, IL-17, } \\
\text { TGF } \beta\end{array}$ & $\begin{array}{l}\text { 1. Alteration of PGD2 and } \\
\text { 2. TXA2 profile }\end{array}$ & \\
\hline $\begin{array}{l}\text { Age-related } \\
\text { hearing loss }\end{array}$ & $\begin{array}{l}\text { 1. Male } \\
\text { 2. Females with } \\
\text { Turner's syndrome }\end{array}$ & Low estrogens & $\mathrm{ER} \alpha / \mathrm{ER} \beta$ & $\begin{array}{l}\text { 1. Cochlear } \\
\text { Macrophages } \\
\text { 2. Cochlear hair cells } \\
\text { 3. Hensen cells }\end{array}$ & $\begin{array}{c}\text { TNF- } \alpha, \text { IL-1 } \beta, \text { IL-6, } \\
\text { IL-8 }\end{array}$ & ANXA1 & [72-104] \\
\hline Sjögren's syndrome & Female & $\begin{array}{l}\text { Low estrogens } \\
\text { (during } \\
\text { menopause) }\end{array}$ & High ER $\beta$ & $\begin{array}{l}\text { 1. Lymphocytes (T } \\
\text { and B cells) } \\
\text { 2. Th17 cells }\end{array}$ & $\begin{array}{l}\text { TNF- } \alpha, \text { IL-1 } \beta, \text { IL-6, } \\
\text { IL-17, IFN } \gamma\end{array}$ & RvD1 & [105-155] \\
\hline $\begin{array}{c}\text { Head and } \\
\text { Neck Cancers }\end{array}$ & Male & Low estrogens & High ER $\alpha / E R \beta / A R$ & $\begin{array}{l}\text { 1. Macrophages } \\
\text { 2. Stromal cells }\end{array}$ & $\begin{array}{l}\text { TNF- } \alpha, \text { IL-6, CXCL10, } \\
\text { COX-2, IL-1a, IL-1b, } \\
\text { IL-4, IL-8, and TGFb }\end{array}$ & $\begin{array}{l}\text { 1.LXA4 } \\
\text { 2. Resolvins (RvD2, RvD4 } \\
\text { and RvD5) }\end{array}$ & [156-197] \\
\hline
\end{tabular}


2. Sex Differences and the Influence of Sex Hormones in ENT Diseases: Sex Hormone Regulation of Inflammatory Responses and Their Resolution

2.1. Chronic Rhinosinusitis

2.1.1. Effect of Sex Hormones on Inflammatory Response in Chronic Rhinosinusitis

CRS is a significant health burden; its global prevalence in the general population is estimated at 1.0-12.1\% [198,199]. CRS is a chronic inflammatory disease of the nasal and sinus mucosa, and can be classified into CRS with nasal polyps (CRSwNP) and CRS without nasal polyps (CRSsNP) $[4,200]$. Increasing reports have suggested that the pathogenesis of these two groups is linked to sex differences. According to these studies, CRSwNP occurs more frequently in males than females, whereas CRSsNP occurs more frequently in females than males. Although men have a higher prevalence of CRSwNP, females are more likely to develop severe symptoms than males [200-204].

The mechanism behind these sex differences observed in CRSwNP is yet to be determined, but the findings presented below provide significant implications for understanding this mechanism. Estrogen receptors (ER $\alpha$ and ER $\beta$ ) are expressed on immune cells and play significant roles in inflammatory responses [38-40]. For example, the activation of the estrogen signaling pathway in ER $\alpha$-expressing eosinophils leads to the degranulation of eosinophils, which causes the release of various proinflammatory factors [41,42]. Therefore, the degranulation of eosinophils is considered a key pathogenic event in chronic eosinophilic diseases, including eosinophilic CRS. Note that the estrogen levels fluctuate during the female menstrual cycle, and this affects the number of eosinophils present in the nasal mucosa $[41,43,202]$. Consistent with the proinflammatory role of estrogens, the reduction of eosinophilic inflammation through tamoxifen, an estrogen antagonist, was observed in an animal asthma model $[44,45]$. Similarly, as high levels of estrogens were found in patients with allergic rhinitis, tamoxifen could inhibit the development of allergic reactions in the nasal cavity in a mouse study through competition with estrogens binding to the ERs $[46,47]$. However, regarding nasal polyps, due to the lack of relevant animal model systems, it remains unclear whether tamoxifen can reduce eosinophilic inflammation.

In clinical studies, the apoptosis of eosinophils is tightly regulated by estrogen during the female menstrual cycle. Therefore, the number of eosinophils remains constant during the menstrual cycle. In contrast, the level of estrogens significantly decreases after menopause, leading to increased numbers of eosinophils in nasal polyp samples compared to healthy donors [48-50]. Interestingly, these studies also suggest that ER $\alpha$ is also highly expressed on the surface of eosinophils [49,50], although the level of estrogens significantly decreases after menopause in patients with nasal polyps. These studies imply that estrogen therapy is useful for post-menopausal women, as the binding of estrogen to ER $\alpha$ was reported to play an important role in regulating the functions of eosinophils, including their mobilization and apoptosis [51]. In summary, inflammation contributes to CRSwNP; thus, a possible explanation for why females are more likely to develop severe CRSwNP symptoms than males involves enhanced inflammatory reactions driven by the levels of sex hormones, such as estrogens.

CRSwNP is also recognized as Th2-dependent eosinophilic nasal inflammation, whereas CRSsNP is known as non-eosinophilic nasal inflammation $[25,52,53,200]$. Estrogens are known to exert significant control on humoral immunity and increase the amount of inflammatory infiltration of eosinophils in the nasal mucosa through stimulation of Th2 cytokine production $[25,52,53,200]$. Females have higher levels of estrogen, which skews the immune response toward Th2, whereas males have higher levels of androgen (AR), such as testosterone, which skews the immune response toward Th1 [52,54,55]. In addition, AR signaling can increase the ratio of lung regulatory $\mathrm{T}$ cells (Tregs) to Th2 cells and reduce eosinophil infiltration and Th2 cytokine production in allergic airway inflammation [56,57]. Therefore, it is evident that females with CRSwNP are more likely to develop severe symptoms than males. Given that female and male hormones usually act in opposing manners, hormone-dependent mechanisms affect the regulation of the 
immune response under both normal and pathological conditions, leading to different disease outcomes between females and males.

\subsubsection{Effect of Sex Hormones on Resolution of Inflammatory Response in} Chronic Rhinosinusitis

Regarding the resolution of the inflammatory response, CRSwNP is defined as an uncontrolled inflammatory disease with nose dysfunction for more than 12 weeks without any sign of resolution [4]. The persistent inflammation of the sinus epithelium, often linked to the accumulation of immune cells (i.e., eosinophils) with inflammatory signals, is intensified into a route in which the natural healing process is misoriented, eventually leading to the destruction of the nasal epithelium [53,198]. Although the underlying role of estrogens in regulating the resolution of uncontrolled inflammation in CRSwNP remains largely unknown, ER polymorphism has been implicated in female airway hypersensitivity and asthma through regulation of the activities of eosinophils, and the regulatory machinery might also play a role in resolving CRSwNP [58,59]. To resolve uncontrolled inflammatory responses, a natural preresolving mechanism that is critical in maintaining tissue homeostasis is apparently altered in CRSwNP under the influence of estrogens [60,61]. For example, a specialized proresolving lipid mediator, lipoxin A4 (LXA4), is critical for reducing innate immune cell trafficking, facilitating the resolution of acute inflammatory responses. LXA4 is an arachidonic acid (AA) metabolite generated from 12/15-lipoxygenase (12/15-LO) enzymes, which exhibit anti-inflammatory effects [62,63]. LXA4 has recently received considerable attention because of its ability to reduce inflammatory conditions and its multifaceted regulation of certain experimental disease models [36,63-65].

For instance, a previous study showed that epithelial cells and peripheral blood derived from aspirin-sensitive patients (higher incidence in females with CRSwNP) had significantly lower levels of LXA4 than aspirin-tolerant patients [66]. Hence, the resolution of inflammation machinery can be altered by the lower levels of LXA4, and thus, chronic inflammation is common in female aspirin-sensitive patients who also have CRSwNP. Considering the hormonal factors in this female-biased disease, these findings further indicate that hormonal status plays a role in regulating the resolution of inflammatory responses, which, if altered, can worsen the disease outcome for these patients.

Recently, many more findings on specialized proresolving mediators (SPMs) in CRSwNP and CRSsNP have been reported $[36,37,61,67]$. SPMs such as resolvin D2 (RvD2), derived from omega-3 fatty acid, are elevated in both CRSwNP and CRSsNP as compared to non-CRS controls [61]. In addition, LXA4 was found to be significantly increased in CRSwNP compared to CRSsNP. This study also found that an alteration of SPM pathways (e.g., RvD2, LXA4, RvD1, LTD4, LTE4, PGD2, and 11 $\beta$ PGF2 $\alpha$ ) was linked to CRSwNP and that an aberrant signaling of SPMs can contribute to persistent inflammation and bacterial colonization in CRS [61]. The cause of such phenomena is unknown, but we speculate that estrogens play a fundamental role. Our speculation is based on the evidence that severe symptoms occur predominantly in females, even though men have a higher prevalence of CRSwNP $[68,69]$. In addition, the dynamic expression of estrogens regulates SPM activity during a proper menstrual cycle, embryo implantation, pregnancy, and delivery [70,71]. Therefore, estrogens can negatively regulate SPM expression, leading to the development of severe CRSwNP in women.

\subsection{Age-Related Hearing Loss}

2.2.1. Effect of Sex Hormones on Inflammatory Response in Age-Related Hearing Loss

The World Health Organization (WHO) estimates that approximately 466 million people worldwide have disabling hearing loss and that this number will increase to 900 million by 2025 [205]. Untreated hearing loss can significantly affect a patient's daily life. For instance, hearing loss in children includes impaired or delayed language and speech development, worsened educational performance, and impaired cognitive development $[72,206]$. In older adults, hearing loss has been independently associated with 
dementia, cognitive impairment, major depressive disorder, social isolation, and increased risks of hospitalization, falls, and mortality $[72,206]$. Hearing loss is more than just an obstacle to communication, and its negative effects permeate and influence all aspects of the lives of those afflicted. According to the Centers for Disease Control and Prevention in the United States, "Those who have hearing loss are more likely to have low employment rates, lower worker productivity, and high healthcare costs", indicating a significant burden of hearing loss on the healthcare system [73,74].

A growing body of evidence has suggested that sex hormones are linked to the differences in hearing loss between aging men and women $[72,75,76]$. The Baltimore Longitudinal Study on Aging showed that tested frequencies declined more frequently in women than in men, particularly in higher frequency regions [77]. Similar to the Baltimore aging study $[77,78]$, another cross-sectional study also found a significant association between serum estradiol levels and hearing thresholds (as measured ranging from 0.5 to $8 \mathrm{kHz}$ ) in post-menopausal women and concluded that lower levels of estrogen are associated with decreased hearing sensitivity [79]. Although women tend to suffer from agerelated hearing loss (ARHL), several studies have suggested that men are exposed to more damaging noise over a lifetime, which may exacerbate ARHL [72,80]. The contributing factors to ARHL in men include differences in working environments and hobbies between the sexes, and these are less likely to be dependent on changes in sex hormonal status in men than in women.

Both clinical and nonclinical studies have suggested that estrogens play a role in protection against ARHL $[75,76,81]$. ER $\alpha$ and ER $\beta$ are expressed in the auditory brainstem and can be regulated by estrogens to respond differently between post-menopausal women and control subjects $[76,82]$. For instance, low estrogen levels during menopause are positively associated with hearing loss [81]. In contrast, a clinical study proved that post-menopausal women receiving estrogen therapy showed protective effects against ARHL $[75,81,83]$. The function of estrogens in hearing protection can also be found in Turner's syndrome $[84,85]$. Females with Turner's syndrome do not produce estrogens, and some young patients often exhibit otitis media and progressive sensorineural hearing loss. In males, the prevalence and severity of ARHL is more pronounced in the absence of confounding factors, such as noise exposure [72]. In addition, males are subjected to weaker otoacoustic emissions due to the high level of androgen hormones produced in-utero during their sexual development $[86,87]$.

The abovementioned studies clearly indicate the existence of sex differences in ARHL. Estrogens are primary hormones in females; unlike the case of CRSwNP, where estrogens elicit eosinophil infiltration, estrogen signaling can play a significant role in regulating cochlear macrophages $[88,89]$. Cochlear macrophages might have a resident purpose in ARHL pathogenesis because these cells express considerable ERs [31,90]. The increased recruitment of macrophages is crucial to mediate the immune response upon infection and is critical for tissue homeostasis. Regarding the ER expression on sensory cells in the cochlea, various types of ERs are expressed in the cochlear hair cells at varying levels, whereas ER $\beta$ seems to play a predominant role in the maintenance of cochlear function during aging or following acoustic trauma [91,92]. Estrogen signaling through ER $\beta$ has been shown to enhance antioxidant, antiapoptotic, and anti-inflammatory responses, all of which can contribute to hearing preservation $[90,93,94]$. Together, the signaling pathway activated by estrogens on different cell types can be manipulated according to different microenvironments, and such compelling results show that we are still just beginning to understand the complete complexities of sex hormones, especially estrogen regulation in sex differences.

\subsubsection{Effect of Sex Hormones on Resolution of Inflammatory Response in Hearing Loss}

While the mechanisms of cochlear resolution remain unclear, significant efforts have been made to understand the main factors involved in the resolution of inflammation in other disease models $[27,29,95]$. Such studies can serve as important evidence for future 
studies on resolving ARHL inflammation. For example, several proresolving mediators that can promote the resolution of inflammation and tissue repair have been characterized, and a key factor identified is the glucocorticoid-inducible protein annexin A1 (ANXA1), which exerts proresolving/anti-inflammatory effects in regulating macrophage activities [84]. Other studies have demonstrated that the function and expression level of ANXA1 can be enhanced by estrogens in various experimental models $[31,33,96]$.

Of all the studies conducted on the cochlear area so far, only one has explored the presence of resolution mediators and their receptors in the cochlea. In particular, the research group found that ANXA1 is secreted by the macrophages or Hensen cells lining the cochlea in the animal model. The results indicated that ANXA1 acts as a bridging or signaling molecule, connecting apoptotic cells to nonprofessional phagocytes and inducing the phagocytosis of apoptotic cells [97]. This signaling network can be indirectly supported by the research result that the treatment of glucocorticoids induces the release of ANXA1 from Hensen cells to strictly regulate the infiltration of leukocytes into the scala media [97]. Consequently, this process can not only promote the clearance of apoptotic cells, but also avoid uncontrolled inflammation and tissue damage caused by excessive leukocyte infiltration. Moreover, ANXA1 facilitates the clearance of apoptotic hair cells by inducing the transformation of supporting cells in the organ of Corti to nonprofessional macrophages $[98,99]$.

The receptor for ANXA1, called ALX/FPR2, is also expressed in the scala media and cells lining the scala tympani and scala vestibule of the cochlea, which are rich in sensory outer hair, inner hair, Deiters, and pillar cells [97]. Therefore, the proresolving ANXA1 released by macrophages or Hensen cells can target the ALX/FPR2 receptor to induce the resolution of inflammation in ARHL. Increasing evidence has suggested that the ALX/FPR2 receptor is expressed on the surface of professional and nonprofessional phagocytic cells, and that its activation via the ANXA1 pathway can promote phagocytosis to clear apoptotic cellular debris $[65,100,101]$. In contrast, loss of ALXF/FPR2 can lead to exacerbated inflammation [102-104]. Together, these nonclinical results suggest that estrogens can modulate macrophage-mediated proresolving actions in the cochlear and that a proresolution therapeutic intervention by targeting macrophages can be important for ameliorating ARHL. However, there are insufficient studies on this topic in the inner ear, and thus, more studies are required.

\subsection{Sjögren's Syndrome}

\subsubsection{Effect of Sex Hormones on Inflammatory Response in Sjögren's Syndrome}

SS is a chronic rheumatic disease characterized by the lymphocytic infiltration of the salivary and lachrymal glands, causing dry eyes and mouth symptoms $[1,2,207,208]$. Although SS is a well-known systemic disease that differs from most ENT diseases, which are localized, its geographical distribution is notable because most patients affected by SS also exhibit otorhinolaryngological manifestations $[1,10,12]$. For instance, patients with SS also show bilateral parotid enlargement, recurrent sinusitis, hearing loss, nasal crust formation, and dysphonia [12-14,209-215]. The incidence rate of SS is estimated to be 6.9 per 100,000 people annually, with an average age of 56 years. SS predominately occurs in females as compared to males at a 9:1 ratio, with distinct immunopathologic differences that are apparently influenced by sex hormones [2,216-220]. Although SS is not a life-threatening disease, its clinical manifestations increase patients' emotional burdens $[14,221-225]$. For example, most SS patients show fatigue, poor sleep quality, and pain due to eye and mucosal dryness $[13,14,222-224,226]$. Moreover, significant lymphocytic infiltration of salivary glands causes uncontrolled inflammatory response, leading to hyposalivation, which is responsible for soreness, adherence of food to the mucosa, dysphagia, difficulties in speaking or eating, dental caries, and periodontal issues, all of which largely affect the patients' quality of life [21,105,226-233]. As otorhinolaryngologists are often the first practitioners to notice if patients show signs of SS, an ENT examination should be 
performed for all patients to devise early diagnosis with prompt treatments or referral to other specialists, preventing morbidity and mortality.

The cause of SS is a multifactorial process that involves interaction between genetic (e.g., HLA, Ro52, IL-10, and TNF $\alpha$ ) and environmental (e.g., EBV virus infection [105-110], comorbid with rheumatoid arthritis (RA), and radiotherapies) factors [14,111-118,207], which lead to aberrant inflammatory responses mediated by lymphocytes (e.g., $\mathrm{T}$ and B cells) and Th17 cells (e.g., IL-17) [76,77,81-85]. When these inflammatory responses are not resolved, they proceed to chronic inflammation, which causes significant tissue damage in the epithelium of exocrine glands $[105,107,228,231]$. As SS mostly affects women, the regulation of sex hormones and inflammation can provide clues for its pathogenesis $[22,216,219,220]$. Increasing evidence has shown that the hallmarks of SS are uncontrolled inflammation (e.g., IFN $\gamma$, IL-1 $\beta$, IL-6, and IL-17) and elevation of autoantibody (i.e., Ro/SSA and La/SSB) production found in the exocrine glands, and that these pathological responses are directly influenced by sex hormones [25,119-131]. For example, estrogen or androgen receptors are expressed in lymphocytes and salivary gland cells $[38,40,132]$. The activation of ERs in B cells results in increased levels of antibodies and autoantibodies, whereas androgens decrease B-cell maturation and reduce antibody and autoantibody production [133-136]. Increased ER- $\beta$ expression in the salivary acinar cells was found to be associated with SS, which is linked to higher susceptibility of apoptosis. Moreover, cytokine receptors, such as the IL-1 receptor, can be found in most hormone-producing tissues (i.e., adrenal glands, placenta, and ovaries) [137-139]. These results indicate a dynamic interplay between sex hormones and the immune system in a normal physiological state and disease progression.

According to the literature, estrogens perform the functions of inducing the differentiation of dendritic cells, stimulating T-cell proliferation, increasing Th2 responses, activating Treg, modulating Th17 responses, and activating M2 tissue healing-type macrophages [38,39,140-142]. In addition, it can inhibit innate Toll-like receptor (TLR) responses and reduce IFN $\gamma$ production in immune cells $[38,143]$. Furthermore, estrogens can protect the disease progression of SS by reducing SS-related proinflammatory responses, such as IL-17, IFN $\gamma$, and autoantibodies Ro/SSA and La/SSB [20,82,144-148,216].

Some clinical studies have further suggested that the loss of estrogens (i.e., menopause) promotes SS development [146,147]. More direct evidence regarding how estrogens regulate SS can be found in some nonclinical studies. For example, a recent study on ovariectomized mice to model menopause showed significantly increased inflammation in the lacrimal and salivary glands, and estrogen replacement successfully reversed this effect by reducing the lymphocytic infiltration in the glands, suggesting that estrogens can directly reduce SS disease progression $[145,149]$. However, estrogens can also act as a double-sided blade in SS development. One significant example is observed in pregnant women, where an increased amount of estrogens promote the production of SS-related autoantibodies Ro/SSA and La/SSB [150,151].

\subsubsection{Effect of Sex Hormones on Resolution of Inflammatory Response in Sjögren's Syndrome}

Sustained and unresolved inflammation has now been recognized as an important feature in many autoimmune diseases, including RA, systemic lupus erythematosus, and SS [152-154]. This unresolved inflammation is attributed to the misregulated acute inflammatory responses, which accumulate proinflammatory signals over time, leading to chronic inflammation with an altered resolution of inflammatory responses [152-154]. Under normal conditions, these acute inflammatory responses are tightly controlled and should be resolved in a timely manner to avoid the occurrence of chronic status [28,30,95]; however, such a proresolving mechanism seems to be altered in SS [155]. In fact, there is a class of chemical mediators produced in our body that can be used to mitigate unresolved inflammation. These chemical mediators are now recognized as SPMs, which have been demonstrated to limit uncontrolled inflammation while promoting natural healing processes by blocking inflammatory cytokine signaling and stimulating tissue 
repair $[27,29,30,234]$. For example, one of these SPMs, called resolvin D1 (RvD1), can prevent the TNF $\alpha$-mediated disruption of the salivary gland epithelium and promote the survival of salivary gland cells in nonclinical studies [35,228,235-237]. In particular, RvD1 can ameliorate SS-like disease progression in an SS-like mouse model by maintaining the integrity and function of the salivary gland epithelium $[35,236,238]$. Furthermore, treatment with AT-RvD1 can increase the saliva flow rate and inhibit the infiltration of Th17 cells in the salivary glands $[35,235,236]$. Note that mice lacking the RvD1 receptor ALX/FPR2 show significant impairment in both innate and adaptive immunities, along with an elevated production of proinflammatory cytokines and antibodies $[103,104,236]$. These results suggest that the resolution of the inflammation pathway is altered in SS, and the use of therapies such as AT-RvD1 can promote the resolution of inflammation to reverse SS progression.

As SS is predominately found in women, several nonclinical studies have also revealed that treatment with RvD1 is more effective in female mice $[35,104]$. Therefore, we can speculate that sex hormones are involved in the resolution of inflammation. Some experimental evidence has suggested that ovariectomized female mice (to mimic menopause) show significantly increased inflammation, and that estrogen replacement can reverse the SS-like phenotype $[145,149]$. These results further demonstrate that sex hormones regulate the resolution of inflammation and tissue homeostasis, especially in salivary glands. However, the underlying mechanism is still limited and requires more evidence to support this notion in a clinical setting. For instance, a recent nonclinical study suggested that sex difference is involved in regulating the resolution of inflammation using an SS-like animal model [155]. The results indicated that the RvD1 level in female mice after developing SS-like features is altered in plasma and saliva. Besides the level of lipid mediators found to be altered in SS-like female mice, the enzymes responsible for SPM synthesis, 5-LOX and 12/15-LOX, were also altered in SS-like female mice. Moreover, female mice lacking the RvD1 receptor ALX/FPR2 showed exacerbated salivary gland inflammation, reduction in saliva flow rate, and increased population of CD-20 positive B cells [104]. In contrast, ALX/FPR2 activation through RvD1 plays a critical role in promoting the resolution of inflammation and regulating antibody production in B cells. Together, these nonclinical studies further indicate that sex hormones play important roles in regulating the resolution of inflammation in SS. However, these results only indicate the potential underlying mechanisms that can elucidate sex differences in SS. Future studies should investigate the SPM level and the activity of SPM biosynthetic enzymes in SS patients.

\subsection{Head and Neck Cancers}

\subsubsection{Effect of Sex Hormones on Inflammatory Response in Head and Neck Cancers}

Numerous epidemiological studies have indicated that sex difference is an important factor for cancer incidence and survival. In general, females have a lower risk and better prognosis than males in most cancer types, such as colon, head and neck, esophagus, lung, and liver $[239,240]$. The higher incidence in the male population can be attributed to diet, occupational exposure (i.e., chemicals or carcinogens), and unhealthy lifestyle (i.e., smoking and alcohol consumption). HNCs (including nasopharyngeal carcinoma and oral squamous cell carcinoma) are examples that display sex difference with a higher incidence rate in males than females at a 5:1 ratio [241-243]. HNCs are the seventh most common tumors worldwide, with an estimated annual burden of 625,173 new cases and 323,160 deaths in 2018. More than $90 \%$ of all HNCs are oral squamous cell carcinoma, arising in the mucosal surface lining the aerodigestive tract [243]. According to the WHO, the incidence rates of HNCs are high in certain Asian-Pacific countries [8,241]. Although their prevalence is low in Western countries, the incidence rates of oral cancer driven by human papillomavirus infections and certain lifestyle habits have increased significantly and become a public health concern $[9,244]$. Besides the multiple factors (i.e., alcohol and smoking) that lead to HNC development, sex hormones can also contribute to head and neck carcinogenesis $[156,157]$. For instance, previous clinical studies on HNC patients have shown that estrogen levels in 
females play a protective role in developing cancer [158-162]. As males have lower levels of estrogen, they are more predisposed to develop cancer. Moreover, the destruction of liver function in alcoholics leads to an alteration in the metabolism of estrogens. Several studies have shown that alcohol can interfere with the balance of sex hormones by promoting the aromatization of androgens into estrogens and thereby impairing the ratio of androgens to estrogen [163-166].

As estrogens and their receptors have been found to be present in oral cavity, laryngeal, or hypopharyngeal cancers, we can speculate that estrogens play a direct role in regulating HNC progression [141,156,157]. For instance, recent studies have suggested that an altered expression of ERs is found in the malignant tissues of oral mucosa and is correlated with HNC survival [156,167]. Moreover, higher estrogen levels are linked with lower HNC risk in women who have undergone hormone replacement therapy, are pregnant, or given birth below 35 years of age [158]. In contrast, higher HNC risk is associated with menopause onset before 52 years of age [158]. Although estrogens have been proven to play a protective role in some studies, other studies have shown opposite results [168,169]. The mechanisms underlying these contradictory results originate from the alteration and fluctuation of endogenous estrogen levels in HNC progression $[156,157]$. In particular, a previous study showed that $75 \%$ of young women who never smoked and drank were HNC patients at age 19-39 years [170], implying that estrogens at different physiological statuses may affect HNC tumorigenesis, probably due to the polymorphism of estrogen and its receptors in the expression level.

Furthermore, increasing evidence has suggested that estrogens can regulate a wide variety of cellular functions, such as anti-inflammation, proliferation, migration, and differentiation of cancer cells and other cells within the tumor microenvironment $[31,38,119,168,171]$. Among the cells involved in the inflammatory tumor microenvironment, the essential player, the macrophage, is involved during all phases of inflammation and can be regulated by estrogens as it expresses ERs [31]. When the immune system fails to resolve inflammation, the chronic inflammatory response dominates and influences important metabolic functions, including cell homeostasis and genomic changes, which eventually lead to the development of carcinogenesis [172-175]. The infiltrated tumor-associated macrophages are major inflammatory cells that promote the progression of malignancies by supporting tumor growth and shaping the tumor microenvironment by secreting proinflammatory cytokines, including the TNF superfamily, interleukins (i.e., IL-1, IL-8, and IL-6), chemokines (i.e., CXCL-10), prostaglandins, and reactive oxygen species (ROS), which promote the development of oral cancers $[175,176]$. Specifically, TNF- $\alpha$, IL-6, and PGE-2 participate in the process of submucous fibrosis, which plays a critical role in enhancing the malignant transformation of oral cancer cells $[177,178]$. Several nonclinical studies have shown that circulating estrogens can regulate the activities of macrophages and reduce inflammatory responses. Specifically, ER activation by estrogens can decrease the synthesis of proinflammatory factors (e.g., TNF $\alpha$, IL-6, and COX-2) in macrophages to clear the damaged proteins through the activation of proteasomes $[179,180]$. Moreover, estrogens inactivate NF-kB-mediated inflammatory responses via the pathway involved in the activation of the estrogen-activated receptor function and phosphatidylinositol 3-kinase [179]. Recent studies have also suggested that estrogens decrease the expression of TLR4, which plays a critical role in producing proinflammatory cytokines $[143,181]$. Therefore, these results suggest that the regulatory function of macrophages can be modulated by estrogen and linked to the reduction of proinflammatory responses that limit the growth of tumors.

However, some opposite results regarding the effect of estrogens in cancers have also been reported. For instance, some experimental studies have suggested that estrogens exhibit genotoxic, mutagenic, and carcinogenic effects. In particular, a previous study suggested that genes or proteins associated with estrogen metabolism (i.e., $\operatorname{ER} \alpha, \operatorname{Er} \beta$, and the androgen receptor) are highly expressed in isolated human head and neck cells and that these molecules can contribute to the tumorigenesis of HNC [157,182,183]. 
In addition to estrogens, other sex hormones, such as androgens, can also contribute to the tumorigenesis of HNC. It has been demonstrated that AR is expressed in patients with oral squamous cell carcinoma (OSCC), and the expression of this receptor is critical for promoting OSCC growth $[184,185]$. A more recent study using clinical samples found that more than $20 \%$ of neoplastic OSSC epithelium patient samples were stained positive with androgen receptors [184]. Considering that ERs and ARs play roles in the tumorigenesis of $\mathrm{HNC}$, the aforementioned studies identify some issues that are worth further investigation, including whether the ratios of the expression levels of estrogen and androgen and their receptors in cancer cells play roles in the tumorigenesis of HNC.

\subsubsection{Effect of Sex Hormones on Resolution of Inflammatory Response in Head and Neck Cancers}

While the cause of HNC has been associated with the abovementioned risk factors, unresolved chronic inflammation has been implicated as a critical driving force that can lead to genetic and epigenetic changes in HNC malignancies [173,178,186,187]. For example, the pathogenesis of oral squamous cancer cells involves several oral inflammatory conditions, such as oral submucous fibrosis, oral lichen planus, discoid lupus erythematosus, oral ulcers related to repetitive tissue injury, and chronic periodontal disease [188,189]. The infiltration of inflammatory cells in oral submucous fibrosis mainly comprises lymphocytes, plasma cells, and macrophages, which are altered by tumor cells to produce proinflammatory cytokines (i.e., TNF- $\alpha$, IL-8, and IL-6), prostaglandins, COX-2, and ROS, elevating the inflammatory status in the local microenvironment, which favors tumor growth $[186,187,190]$. Therefore, targeting these tumor-associated inflammatory factors appears to be a tempting strategy to devise novel therapeutics for treating oral cancers.

Furthermore, recent studies have explained the application of SPMs that can resolve uncontrolled inflammation and maintain tissue homeostasis. These SPMs are derived from $\omega-3$ or $\omega-6$ polyunsaturated fatty acids through enzymatic processing with lipoxygenases (i.e., 5- and 12/15-LO) [32,191-193]. For example, resolvins and lipoxins are SPMs that can be naturally synthesized from AA, docosahexaenoic acid and aspirin, and perform potent proresolving and anti-inflammatory functions by regulating the infiltration of immune cells, removing apoptotic cell debris, inhibiting the synthesis of proinflammatory cytokines (e.g., TNF- $\alpha$, IL-6, CXCL10, COX-2, and MCP-1), and inhibiting tumor migration/metastasis [32,191-194]. These findings suggest the proresolving actions of SPMs in anticancer functions. Although the involvement of sex hormones in regulating the biological events between SPMs and HNC remains unclear, a recent study has suggested a potential link of how estrogens regulate the resolution of inflammation in HNC. In particular, a proresolving mediator, LXA4, has been found to share structural similarities with estrogens (i.e., estrogen 17-estradiol) and compete with ER to inhibit estrogen's function, which indicates the therapeutic potential of LXA4 in treating estrogen-associated diseases, such as cancers $[64,195]$. Moreover, LXA4 or another proresolving mediator RvD1 can inhibit estrogen-induced epithelial-mesenchymal transition through ALX/FPR2 receptor signaling in several disease models, including endometriosis, lung cancer, and nasopharyngeal carcinoma $[31,34,100,103,155,177,193,196,197]$. Together, these results further imply an important link between estrogens and the resolution of inflammation in HNC; however, the exact mechanism remains largely unknown.

\section{Conclusions}

This review article aims to highlight the interconnections among sex hormones, ENT diseases, and immune responses. We discussed several ENT diseases that involve both sex hormones and immune responses, and found that sex hormones play important roles in regulating inflammatory responses and resolution of inflammation after tissue injury. In addition, we reviewed the recent findings that have shown that the machinery in immune response is mostly altered in ENT diseases under the influence of hormonal status (Table 1).

To date, studies addressing the role of estrogens in ENT diseases have largely been restrained by significant experimental obstacles. For example, most in vitro settings con- 
ducted using exogenous estrogens or antagonists to ERs are too simplified to address the complex in vivo system. Moreover, the dose, duration, and route of estrogen treatment in both in vitro and in vivo models should be considered as important factors in future experimental designs. Estrogen signaling can exert completely opposite effects on ENT diseases for improvement or augmentation, depending on the microenvironment and cell type.

In conclusion, estrogens and other sex hormones play important roles in regulating the immune system and thus influence the disease outcomes. Hence, increased efforts are required to identify their functions in terms of driving the inflammation and its resolution in ENT diseases. This is particularly important given that the established importance of sex differences in ENT disease can yield a novel therapeutic strategy to ameliorate or reverse ENT disease progression.

Author Contributions: S.-D.L., T.-J.C., W.-C.C. and C.-S.W. studied papers and wrote the manuscript; S.-D.L. and C.-S.W. reviewed and confirmed; T.-J.C., W.-C.C. and C.-S.W. reviewed and commented; C.-S.W. supervised and funded the study. All authors have read and agreed to the published version of the manuscript.

Funding: This research was supported by the Ministry of Science and Technology (MOST), Taiwan, under grant number 110-2320-B-038-015.

Institutional Review Board Statement: Not applicable.

Informed Consent Statement: Not applicable.

Data Availability Statement: No new data were created or analyzed in this study. Data sharing is not applicable to this article. Data available in a publicly accessible repository.

Conflicts of Interest: The authors declare no conflict of interest.

\section{References}

1. Atkinson, J.C.; Fox, P.C. Sjogren's Syndrome: Oral and Dental Considerations. J. Am. Dent. Assoc. 1993, 124, 74-76, 78-82, 84-86. [CrossRef] [PubMed]

2. Delaleu, N.; Jonsson, R.; Koller, M.M. Sjogren's syndrome. Eur. J. Oral. Sci. 2005, 113, 101-113. [CrossRef]

3. Bhurgri, Y.; Bhurgri, A.; Usman, A.; Pervez, S.; Kayani, N.; Bashir, I.; Ahmed, R.; Hasan, S.H. Epidemiological Review of Head and Neck Cancers in Karachi. Asian Pac. J. Cancer Prev. 2006, 7, 195. [PubMed]

4. Dietz de Loos, D.A.; Hopkins, C.; Fokkens, W.J. Symptoms in Chronic Rhinosinusitis with and without Nasal Polyps. Laryngoscope 2013, 123, 57-63. [CrossRef]

5. Dhingra, P.; Dhingra, S. Diseases of Ear, Nose and Throat-EBook; Elsevier: New Delhi, India, 2017; ISBN 81-312-4939-5.

6. Michaels, L.; Hellquist, H.B. Ear, Nose and Throat Histopathology; Springer Science \& Business Media: Berlin, Germany, 2001; ISBN 3-540-76142-X.

7. Rao, S.V.K.; Mejia, G.; Roberts-Thomson, K.; Logan, R. Epidemiology of Oral Cancer in Asia in the Past Decade-An Update (2000-2012). Asian Pac. J. Cancer Prev. 2013, 14, 5567-5577. [CrossRef]

8. Adel, M.; Liao, C.-T.; Lee, L.-Y.; Hsueh, C.; Lin, C.-Y.; Fan, K.-H.; Wang, H.-M.; Ng, S.-H.; Lin, C.-H.; Tsao, C.-K.; et al. Incidence and Outcomes of Patients With Oral Cavity Squamous Cell Carcinoma and Fourth Primary Tumors: A Long-Term Follow-up Study in a Betel Quid Chewing Endemic Area. Medicine 2016, 95, e2950. [CrossRef] [PubMed]

9. Götz, C.; Drecoll, E.; Straub, M.; Bissinger, O.; Wolff, K.-D.; Kolk, A. Impact of HPV Infection on Oral Squamous Cell Carcinoma. Oncotarget 2016, 7, 76704-76712. [CrossRef]

10. Hofauer, B.; Chaker, A.; Thürmel, K.; Knopf, A. Manifestations of Autoimmune Disorders in Otorhinolaryngology: Classical Symptoms and Diagnostic Approach. HNO 2017, 65, 695-708. [CrossRef]

11. Ralli, M.; de Vincentiis, M. Autoimmunity and Otolaryngology Diseases. J. Immunol. Res. 2018, 2018. [CrossRef]

12. Angeletti, D.; Iannella, G.; Ciofalo, A.; Re, M.; Plateroti, R.; Plateroti, P.; Pasquariello, B.; Manno, A.; Didona, D.; Magliulo, G. Otorhinolaryngological Manifestations in Sjogren Syndrome. Curr. Immunol. Rev. 2018, 14, 24-30. [CrossRef]

13. Hou, T.; Hsu, H.; Lin, T.; Chang, Y.; Chen, W.; Kuo, P.; Lin, Y.; Chang, C.; Chen, J. Higher Risk of Dementia in Primary Sjogren's Syndrome. Ann. Clin. Transl. Neurol. 2019, 6, 633-641. [CrossRef] [PubMed]

14. Chen, H.-H.; Perng, W.-T.; Chiou, J.-Y.; Wang, Y.-H.; Huang, J.-Y.; Wei, J.C.-C. Risk of Dementia among Patients with Sjogren's Syndrome: A Nationwide Population-Based Cohort Study in Taiwan; Elsevier: Amsterdam, The Netherlands, 2019; Volume 48, pp. 895-899.

15. ROSEN, S.; Olin, P. Hearing Loss and Coronary Heart Disease. Arch. Otolaryngol. 1965, 82, 236-243. [CrossRef] 
16. Lin, C.; Lee, K.; Yu, S.; Lin, Y. Effect of Comorbid Diabetes and Hypercholesterolemia on the Prognosis of Idiopathic Sudden Sensorineural Hearing Loss. Laryngoscope 2016, 126, 142-149. [CrossRef]

17. Şereflican, M.; Kurt, Ö.K. Otorhinolaryngologic Manifestations in Obstructive Sleep Apnea. Acta Med. Anatol. 2016, 4, 32-36. [CrossRef]

18. Lauretta, R.; Sansone, M.; Sansone, A.; Romanelli, F.; Appetecchia, M. Gender in Endocrine Diseases: Role of Sex Gonadal Hormones. Int. J. Endocrinol. 2018, 2018, 1-11. [CrossRef]

19. Foo, Y.Z.; Nakagawa, S.; Rhodes, G.; Simmons, L.W. The Effects of Sex Hormones on Immune Function: A Meta-analysis. Biol. Rev. 2017, 92, 551-571. [CrossRef] [PubMed]

20. Roved, J.; Westerdahl, H.; Hasselquist, D. Sex Differences in Immune Responses: Hormonal Effects, Antagonistic Selection, and Evolutionary Consequences. Horm. Behav. 2017, 88, 95-105. [CrossRef]

21. Takahashi, T.; Iwasaki, A. Sex Differences in Immune Responses. Science 2021, 371, 347-348. [CrossRef]

22. Ahmed, S.A.; Penhale, W.; Talal, N. Sex Hormones, Immune Responses, and Autoimmune Diseases. Mechanisms of Sex Hormone Action. Am. J. Pathol. 1985, 121, 531.

23. Taneja, V. Sex Hormones Determine Immune Response. Front. Immunol. 2018, 9, 1931. [CrossRef]

24. Burrows, H. Biological Actions of Sex Hormones; Cambridge University Press: Cambridge, UK, 2013; ISBN 1-107-62550-5.

25. Giron-Gonzalez, J.; Moral, F.J.; Elvira, J.; Garcia-Gil, D.; Guerrero, F.; Gavilan, I.; Escobar, L. Consistent Production of a Higher T H1: T H2 Cytokine Ratio by Stimulated T Cells in Men Compared with Women. Eur. J. Endocrinol. 2000, 143, 31-36. [CrossRef] [PubMed]

26. Mo, R.; Chen, J.; Grolleau-Julius, A.; Murphy, H.S.; Richardson, B.C.; Yung, R.L. Estrogen Regulates CCR Gene Expression and Function in T Lymphocytes. J. Immunol. 2005, 174, 6023-6029. [CrossRef] [PubMed]

27. Bannenberg, G.; Serhan, C.N. Specialized pro-resolving lipid mediators in the inflammatory response: An update. Biochim. Biophys. Acta BBA-Mol. Cell Biol. Lipids 2010, 1801, 1260-1273. [CrossRef]

28. Serhan, C.N.; Savill, J. Resolution of Inflammation: The Beginning Programs the End. Nat. Immunol. 2005, 6, 1191-1197. [CrossRef]

29. Zahoor, I.; Giri, S. Specialized Pro-Resolving Lipid Mediators: Emerging Therapeutic Candidates for Multiple Sclerosis. Clin. Rev. Allergy Immunol. 2021, 60, 147-163. [CrossRef]

30. Chiurchiù, V.; Leuti, A.; Dalli, J.; Jacobsson, A.; Battistini, L.; Maccarrone, M.; Serhan, C.N. Proresolving Lipid Mediators Resolvin D1, Resolvin D2, and Maresin 1 Are Critical in Modulating T Cell Responses. Sci. Transl. Med. 2016, 8, 353ra111. [CrossRef]

31. Villa, A.; Rizzi, N.; Vegeto, E.; Ciana, P.; Maggi, A. Estrogen Accelerates the Resolution of Inflammation in Macrophagic Cells. Sci. Rep. 2015, 5, 15224. [CrossRef]

32. Zhang, Q.; Zhu, B.; Li, Y. Resolution of Cancer-Promoting Inflammation: A New Approach for Anticancer Therapy. Front. Immunol. 2017, 8, 71. [CrossRef]

33. Loiola, R.A.; Wickstead, E.S.; Solito, E.; McArthur, S. Estrogen Promotes Pro-Resolving Microglial Behavior and Phagocytic Cell Clearance through the Actions of Annexin A1. Front. Endocrinol. 2019, 10, 420. [CrossRef] [PubMed]

34. Sun, L.; Wang, Y.; Wang, L.; Yao, B.; Chen, T.; Li, Q.; Liu, Z.; Liu, R.; Niu, Y.; Song, T. Resolvin D1 Prevents Epithelial-Mesenchymal Transition and Reduces the Stemness Features of Hepatocellular Carcinoma by Inhibiting Paracrine of Cancer-Associated Fibroblast-Derived COMP. J. Exp. Clin. Cancer Res. 2019, 38, 1-17. [CrossRef] [PubMed]

35. Wang, C.-S.; Maruyama, C.L.; Easley, J.T.; Trump, B.G.; Baker, O.J. AT-RvD1 Promotes Resolution of Inflammation in NOD/ShiLtJ Mice. Sci. Rep. 2017, 7, 45525. [CrossRef] [PubMed]

36. Pérez-Novo, C.A.; Watelet, J.B.; Claeys, C.; Van Cauwenberge, P.; Bachert, C. Prostaglandin, Leukotriene, and Lipoxin Balance in Chronic Rhinosinusitis with and without Nasal Polyposis. J. Allergy Clin. Immunol. 2005, 115, 1189-1196. [CrossRef] [PubMed]

37. Levy, B.D. Resolvin D1 and Resolvin E1 Promote the Resolution of Allergic Airway Inflammation via Shared and Distinct Molecular Counter-Regulatory Pathways. Front. Immun. 2012, 3, 390. [CrossRef]

38. Kovats, S. Estrogen Receptors Regulate Innate Immune Cells and Signaling Pathways. Cell. Immunol. 2015, 294, 63-69. [CrossRef] [PubMed]

39. Lélu, K.; Laffont, S.; Delpy, L.; Paulet, P.-E.; Périnat, T.; Tschanz, S.A.; Pelletier, L.; Engelhardt, B.; Guéry, J.-C. Estrogen Receptor $\alpha$ Signaling in T Lymphocytes Is Required for Estradiol-Mediated Inhibition of Th1 and Th17 Cell Differentiation and Protection against Experimental Autoimmune Encephalomyelitis. J. Immunol. 2011, 187, 2386-2393. [CrossRef]

40. Phiel, K.L.; Henderson, R.A.; Adelman, S.J.; Elloso, M.M. Differential Estrogen Receptor Gene Expression in Human Peripheral Blood Mononuclear Cell Populations. Immunol. Lett. 2005, 97, 107-113. [CrossRef]

41. Cai, Y.; Zhou, J.; Webb, D.C. Estrogen Stimulates Th2 Cytokine Production and Regulates the Compartmentalisation of Eosinophils during Allergen Challenge in a Mouse Model of Asthma. Int. Arch. Allergy Immunol. 2012, 158, 252-260. [CrossRef]

42. Tchernitchin, A.N.; Barrera, J.; Arroyo, P.; Mena, M.A.; Vilches, K.; Grunert, G. Degranulatory Action of Estradiol on Blood Eosinophil Leukocytes in Vivo and in Vitro. Agents Actions 1985, 17, 60-66. [CrossRef]

43. Gordon, J.L.; Peltier, A.; Grummisch, J.A.; Sykes Tottenham, L. Estradiol Fluctuation, Sensitivity to Stress, and Depressive Symptoms in the Menopause Transition: A Pilot Study. Front. Psychol. 2019, 10, 1319. [CrossRef]

44. Riffo-Vasquez, Y.; Ligeiro de Oliveira, A.; Page, C.; Spina, D.; Tavares-de-Lima, W. Role of Sex Hormones in Allergic Inflammation in Mice. Clin. Exp. Allergy 2007, 37, 459-470. [CrossRef]

45. Mainguy-Seers, S.; Picotte, K.; Lavoie, J. Efficacy of Tamoxifen for the Treatment of Severe Equine Asthma. J. Vet. Intern. Med. 2018, 32, 1748-1753. [CrossRef] 
46. Dong, Z.; Zhu, J.; Sun, S. The Effect of Tamoxifen on Experimental Nasal Hypersensitivity. Lin Chuang Er Bi Yan Hou Ke Za Zhi= J. Clin. Otorhinolaryngol. 1998, 12, 174-176.

47. Jones, B.G.; Penkert, R.R.; Surman, S.L.; Sealy, R.E.; Pelletier, S.; Xu, B.; Neale, G.; Maul, R.W.; Gearhart, P.J.; Hurwitz, J. Matters of Life and Death: How Estrogen and Estrogen Receptor Binding to the Immunoglobulin Heavy Chain Locus May Influence Outcomes of Infection, Allergy, and Autoimmune Disease. Cell. Immunol. 2019, 346, 103996. [CrossRef] [PubMed]

48. Lou, H.; Zhang, N.; Bachert, C.; Zhang, L. Highlights of Eosinophilic Chronic Rhinosinusitis with Nasal Polyps in Definition, Prognosis, and Advancement; Wiley Online Library: Hoboken, NJ, USA, 2018; Volume 8, pp. 1218-1225.

49. Machado-Carvalho, L.; Torres, R.; Perez-Gonzalez, M.; Alobid, I.; Mullol, J.; Pujols, L.; Roca-Ferrer, J.; Picado, C. Altered Expression and Signalling of EP2 Receptor in Nasal Polyps of AERD Patients: Role in Inflammation and Remodelling. Rhinology 2016, 54, 254-265. [CrossRef]

50. Bahçeci, S.; Şimşek, F.; Eren, E.; Aladağ, I. Akt and Estrogen Receptor Expression in Nasal Polyps. Indian J. Pathol. Microbiol. 2019, 62, 375. [CrossRef] [PubMed]

51. Douin-Echinard, V.; Calippe, B.; Billon-Galès, A.; Fontaine, C.; Lenfant, F.; Trémollières, F.; Bayard, F.; Guéry, J.; Arnal, J.; Gourdy, P. Estradiol Administration Controls Eosinophilia through Estrogen Receptor- $\alpha$ Activation during Acute Peritoneal Inflammation. J. Leukoc. Biol. 2011, 90, 145-154. [CrossRef] [PubMed]

52. Ekinci, A.; Ozcan, M. Levels of Th1 and Th2 Cytokines in Patients with Nasal Polyps. J. Clin. Exp. Investig. 2018, 9, 71-75. [CrossRef]

53. Sánchez-Segura, A.; Brieva, J.A.; Rodríguez, C. T Lymphocytes That Infiltrate Nasal Polyps Have a Specialized Phenotype and Produce a Mixed TH1/TH2 Pattern of Cytokines. J. Allergy Clin. Immunol. 1998, 102, 953-960. [CrossRef]

54. Martin, J.T. Sexual Dimorphism in Immune Function: The Role of Prenatal Exposure to Androgens and Estrogens. Eur. J. Pharmacol. 2000, 405, 251-261. [CrossRef]

55. Angele, M.K.; Knöferl, M.W.; Ayala, A.; Bland, K.I.; Chaudry, I.H. Testosterone and Estrogen Differently Effect Th1 and Th2 Cytokine Release Following Trauma-Haemorrhage. Cytokine 2001, 16, 22-30. [CrossRef]

56. Gandhi, V.; Cephus, J.; Chowdhury, N.; Norlander, A.; Peebles, S.; Newcomb, D. Androgen Receptor Signaling Augments Regulatory T Cell Functions to Attenuate Allergic Airway Inflammation. J. Allergy Clin. Immunol. 2021, 147, AB3. [CrossRef]

57. Walecki, M.; Eisel, F.; Klug, J.; Baal, N.; Paradowska-Dogan, A.; Wahle, E.; Hackstein, H.; Meinhardt, A.; Fijak, M. Androgen Receptor Modulates Foxp3 Expression in CD4 ${ }^{+}$CD25+ Foxp3 ${ }^{+}$Regulatory T-Cells. Mol. Biol. Cell 2015, 26, 2845-2857. [PubMed]

58. Bloodworth, M.H.; Rusznak, M.; Bastarache, L.; Wang, J.; Newcomb, D.C. Estrogen Receptor-Alpha (ESR1) Polymorphism Rs1999805 Associates with Asthma. Ann. Allergy Asthma Immunol. Off. Publ. Am. Coll. Allergy Asthma Immunol. 2019, $122,208$. [CrossRef] [PubMed]

59. Dijkstra, A.; Howard, T.D.; Vonk, J.M.; Ampleford, E.J.; Lange, L.A.; Bleecker, E.R.; Meyers, D.A.; Postma, D.S. Estrogen Receptor 1 Polymorphisms Are Associated with Airway Hyperresponsiveness and Lung Function Decline, Particularly in Female Subjects with Asthma. J. Allergy Clin. Immunol. 2006, 117, 604-611. [CrossRef]

60. Espersen, J.; Weber, U.; Römer-Franz, A.; Lenarz, T.; Stolle, S.R.; Warnecke, A. Level of Sex Hormones and Their Association with Acetylsalicylic Acid Intolerance and Nasal Polyposis. PLoS ONE 2020, 15, e0243732.

61. Vickery, T.W.; Armstrong, M.; Kofonow, J.M.; Robertson, C.E.; Kroehl, M.E.; Reisdorph, N.A.; Ramakrishnan, V.R.; Frank, D.N. Altered Tissue Specialized Pro-Resolving Mediators in Chronic Rhinosinusitis. Prostaglandins Leukot. Essent. Fat. Acids 2021, 164, 102218. [CrossRef]

62. Takano, T.; Fiore, S.; Maddox, J.F.; Brady, H.R.; Petasis, N.A.; Serhan, C.N. Aspirin-Triggered 15-Epi-Lipoxin A 4 (LXA 4 ) and LXA 4 Stable Analogues Are Potent Inhibitors of Acute Inflammation: Evidence for Anti-Inflammatory Receptors. J. Exp. Med. 1997, 185, 1693-1704. [CrossRef]

63. Fu, T.; Mohan, M.; Brennan, E.P.; Woodman, O.L.; Godson, C.; Kantharidis, P.; Ritchie, R.H.; Qin, C.X. Therapeutic Potential of Lipoxin $\mathrm{A}_{4}$ in Chronic Inflammation: Focus on Cardiometabolic Disease. ACS Pharmacol. Transl. Sci. 2020, 3, 43-55. [CrossRef] [PubMed]

64. Macdonald, L.J.; Boddy, S.C.; Denison, F.C.; Sales, K.J.; Jabbour, H.N. A Role for Lipoxin A 4 as an Anti-Inflammatory Mediator in the Human Endometrium. Reproduction 2011, 142, 345-352. [CrossRef] [PubMed]

65. Petri, M.H.; Thul, S.; Andonova, T.; Lindquist-Liljeqvist, M.; Jin, H.; Skenteris, N.-T.; Arnardottir, H.; Maegdefessel, L.; Caidahl, K.; Perretti, M. Resolution of Inflammation through the Lipoxin and ALX/FPR2 Receptor Pathway Protects against Abdominal Aortic Aneurysms. JACC Basic Transl. Sci. 2018, 3, 719-727. [CrossRef]

66. Sanak, M.; Levy, B.; Clish, C.; Chiang, N.; Gronert, K.; Mastalerz, L.; Serhan, C.; Szczeklik, A. Aspirin-Tolerant Asthmatics Generate More Lipoxins than Aspirin-Intolerant Asthmatics. Eur. Respir. J. 2000, 16, 44-49. [CrossRef] [PubMed]

67. Attia, T.M. Role of Omega-3 Polyunsaturated Fatty Acids in Treatment of Nasal Polyposis. Am. J. Rhinol. Allergy 2020, 34, 43-49. [CrossRef]

68. Drake-Lee, A.; Lowe, D.; Swanston, A.; Grace, A. Clinical Profile and Recurrence of Nasal Polyps. J. Laryngol. Otol. 1984, 98, 783-793. [CrossRef] [PubMed]

69. Hulse, K.E.; Stevens, W.W.; Tan, B.K.; Norton, J.; Suh, L.; Kern, R.C.; Conley, D.; Chandra, R.; Peters, A.T.; Grammer, L.C. Sex-Specific Differences in Disease Severity in Patients with Chronic Rhinosinusitis with Nasal Polyps. J. Allergy Clin. Immunol. 2014, 133, AB169. [CrossRef] 
70. Szczuko, M.; Palma, J.; Kikut, J.; Komorniak, N.; Ziętek, M. Changes of Lipoxin Levels during Pregnancy and the Monthly-Cycle, Condition the Normal Course of Pregnancy or Pathology. Inflamm. Res. 2020, 69, 869-881. [CrossRef]

71. Xu, Z.; Zhao, S.; Zhou, T.; Liao, T.; Huang, X.; Xiang, H.; Zhang, Q.; Huang, Y.; Lin, F.; Ye, D. Lipoxin A4 Interferes with Embryo Implantation via Suppression of Epithelial-mesenchymal Transition. Am. J. Reprod. Immunol. 2019, 81, e13107. [CrossRef]

72. Homans, N.C.; Metselaar, R.M.; Dingemanse, J.G.; van der Schroeff, M.P.; Brocaar, M.P.; Wieringa, M.H.; Baatenburg de Jong, R.J.; Hofman, A.; Goedegebure, A. Prevalence of Age-related Hearing Loss, Including Sex Differences, in Older Adults in a Large Cohort Study. Laryngoscope 2017, 127, 725-730. [CrossRef] [PubMed]

73. Reed, N.S.; Altan, A.; Deal, J.A.; Yeh, C.; Kravetz, A.D.; Wallhagen, M.; Lin, F.R. Trends in Health Care Costs and Utilization Associated with Untreated Hearing Loss over 10 Years. JAMA Otolaryngol.-Head Neck Surg. 2019, 145, 27-34. [CrossRef] [PubMed]

74. National Academies of Sciences, Engineering, and Medicine. Hearing Health Care for Adults: Priorities for Improving Access and Affordability; National Academies Press: Washington, DC, USA, 2016; ISBN 0-309-43929-9.

75. Hultcrantz, M.; Simonoska, R.; Stenberg, A.E. Estrogen and Hearing: A Summary of Recent Investigations. Acta Oto-Laryngol. 2006, 126, 10-14. [CrossRef] [PubMed]

76. Shuster, B.Z.; Depireux, D.A.; Mong, J.A.; Hertzano, R. Sex Differences in Hearing: Probing the Role of Estrogen Signaling. J. Acoust. Soc. Am. 2019, 145, 3656-3663. [CrossRef]

77. Shock, N.W. Normal Human Aging: The Baltimore Longitudinal Study of Aging; NIH Publication: Washington, DC, USA, 1984.

78. Lin, F.R.; Ferrucci, L.; Metter, E.J.; An, Y.; Zonderman, A.B.; Resnick, S.M. Hearing Loss and Cognition in the Baltimore Longitudinal Study of Aging. Neuropsychology 2011, 25, 763. [CrossRef] [PubMed]

79. Curhan, S.G.; Eliassen, A.H.; Eavey, R.D.; Wang, M.; Lin, B.M.; Curhan, G.C. Menopause and Postmenopausal Hormone Therapy and Risk of Hearing Loss. Menopause 2017, 24, 1049. [CrossRef]

80. Villavisanis, D.F.; Berson, E.R.; Lauer, A.M.; Cosetti, M.K.; Schrode, K.M. Sex-Based Differences in Hearing Loss: Perspectives From Non-Clinical Research to Clinical Outcomess. Otol. Neurotol. 2020, 41, 290-298. [CrossRef]

81. Kilicdag, E.B.; Yavuz, H.; Bagis, T.; Tarim, E.; Erkan, A.N.; Kazanci, F. Effects of Estrogen Therapy on Hearing in Postmenopausal Women. Am. J. Obstet. Gynecol. 2004, 190, 77-82. [CrossRef]

82. Tsinti, M.; Kassi, E.; Korkolopoulou, P.; Kapsogeorgou, E.; Moutsatsou, P.; Patsouris, E.; Manoussakis, M.N. Functional Estrogen Receptors Alpha and Beta Are Expressed in Normal Human Salivary Gland Epithelium and Apparently Mediate Immunomodulatory Effects. Eur. J. Oral Sci. 2009, 117, 498-505. [CrossRef]

83. Williamson, T.T.; Ding, B.; Zhu, X.; Frisina, R.D. Hormone Replacement Therapy Attenuates Hearing Loss: Mechanisms Involving Estrogen and the IGF-1 Pathway. Aging Cell 2019, 18, e12939. [CrossRef]

84. Morgan, T. Turner Syndrome: Diagnosis and Management. Am. Fam. Physician 2007, 76, 405-410. [PubMed]

85. Shankar, R.K.; Backeljauw, P.F. Current Best Practice in the Management of Turner Syndrome. Ther. Adv. Endocrinol. Metab. 2018, 9, 33-40. [CrossRef]

86. McFadden, D. Masculinization of the Mammalian Cochlea. Hear. Res. 2009, 252, 37-48. [CrossRef]

87. McFadden, D.; Martin, G.K.; Stagner, B.B.; Maloney, M.M. Sex Differences in Distortion-Product and Transient-Evoked Otoacoustic Emissions Compared. J. Acoust. Soc. Am. 2009, 125, 239-246. [CrossRef] [PubMed]

88. Wood, M.B.; Zuo, J. The Contribution of Immune Infiltrates to Ototoxicity and Cochlear Hair Cell Loss. Front. Cell. Neurosci. 2017, 11, 106. [CrossRef]

89. Zhang, W.; Dai, M.; Fridberger, A.; Hassan, A.; DeGagne, J.; Neng, L.; Zhang, F.; He, W.; Ren, T.; Trune, D.; et al. PerivascularResident Macrophage-like Melanocytes in the Inner Ear Are Essential for the Integrity of the Intrastrial Fluid-Blood Barrier. Proc. Natl. Acad. Sci. USA 2012, 109, 10388-10393. [CrossRef]

90. Delhez, A.; Lefebvre, P.; Péqueux, C.; Malgrange, B.; Delacroix, L. Auditory Function and Dysfunction: Estrogen Makes a Difference. Cell. Mol. Life Sci. 2020, 77, 619-635. [CrossRef]

91. Charitidi, K.; Meltser, I.; Tahera, Y.; Canlon, B. Functional Responses of Estrogen Receptors in the Male and Female Auditory System. Hear. Res. 2009, 252, 71-78. [CrossRef]

92. Stenberg, A.; Wang, H.; Fish Iii, J.; Schrott-Fischer, A.; Sahlin, L.; Hultcrantz, M. Estrogen Receptors in the Normal Adult and Developing Human Inner Ear and in Turner's Syndrome. Hear. Res. 2001, 157, 87-92. [CrossRef]

93. Nakamagoe, M.; Tabuchi, K.; Uemaetomari, I.; Nishimura, B.; Hara, A. Estradiol Protects the Cochlea against Gentamicin Ototoxicity through Inhibition of the JNK Pathway. Hear. Res. 2010, 261, 67-74. [CrossRef]

94. Thakkar, R.; Wang, R.; Sareddy, G.; Wang, J.; Thiruvaiyaru, D.; Vadlamudi, R.; Zhang, Q.; Brann, D. NLRP3 Inflammasome Activation in the Brain after Global Cerebral Ischemia and Regulation by 17 $\beta$-Estradiol. Oxidative Med. Cell. Longev. 2016, 2016. [CrossRef] [PubMed]

95. Buckley, C.D.; Gilroy, D.W.; Serhan, C.N.; Stockinger, B.; Tak, P.P. The Resolution of Inflammation. Nat. Rev. Immunol. 2013, 13, 59-66. [CrossRef] [PubMed]

96. Sheikh, M.H.; Solito, E. Annexin A1: Uncovering the Many Talents of an Old Protein. Int. J. Mol. Sci. 2018, 19, 1045. [CrossRef] [PubMed]

97. Kalinec, F.; Webster, P.; Maricle, A.; Guerrero, D.; Chakravarti, D.; Chakravarti, B.; Gellibolian, R.; Kalinec, G. Glucocorticoidstimulated, Transcription-independent Release of Annexin A1 by Cochlear Hensen Cells. Br. J. Pharmacol. 2009, 158, 1820-1834. [CrossRef] 
98. Tornabene, S.V.; Sato, K.; Pham, L.; Billings, P.; Keithley, E.M. Immune Cell Recruitment Following Acoustic Trauma. Hear. Res. 2006, 222, 115-124. [CrossRef]

99. Hirose, K.; Discolo, C.M.; Keasler, J.R.; Ransohoff, R. Mononuclear Phagocytes Migrate into the Murine Cochlea after Acoustic Trauma. J. Comp. Neurol. 2005, 489, 180-194. [CrossRef] [PubMed]

100. Corminboeuf, O.; Leroy, X. FPR2/ALXR Agonists and the Resolution of Inflammation. J. Med. Chem. 2015, 58, 537-559. [CrossRef]

101. Cooray, S.N.; Gobbetti, T.; Montero-Melendez, T.; McArthur, S.; Thompson, D.; Clark, A.J.; Flower, R.J.; Perretti, M. LigandSpecific Conformational Change of the G-Protein-Coupled Receptor ALX/FPR2 Determines Proresolving Functional Responses. Proc. Natl. Acad. Sci. USA 2013, 110, 18232-18237. [CrossRef]

102. Kain, V.; Jadapalli, J.K.; Tourki, B.; Halade, G.V. Inhibition of FPR2 Impaired Leukocytes Recruitment and Elicited Non-Resolving Inflammation in Acute Heart Failure. Pharmacol. Res. 2019, 146, 104295. [CrossRef]

103. Wang, C.-S.; Wee, Y.; Yang, C.-H.; Melvin, J.E.; Baker, O.J. ALX/FPR2 Modulates Anti-Inflammatory Responses in Mouse Submandibular Gland. Sci. Rep. 2016, 6, 24244. [CrossRef]

104. Wang, C.-S.; Baker, O.J. The G-Protein-Coupled Receptor ALX/Fpr2 Regulates Adaptive Immune Responses in Mouse Submandibular Glands. Am. J. Pathol. 2018, 188, 1555-1562. [CrossRef]

105. Pontarini, E.; Lucchesi, D.; Bombardieri, M. Current Views on the Pathogenesis of Sjögren's Syndrome. Curr. Opin. Rheumatol. 2018, 30, 215-221. [CrossRef] [PubMed]

106. Maslinska, M. The Role of Epstein-Barr Virus Infection in Primary Sjögren's Syndrome. Curr. Opin. Rheumatol. 2019, 31, 475-483. [CrossRef] [PubMed]

107. Björk, A.; Mofors, J.; Wahren-Herlenius, M. Environmental Factors in the Pathogenesis of Primary Sjögren's Syndrome. J. Intern. Med. 2020, 287, 475-492. [CrossRef] [PubMed]

108. Nakamura, H.; Kawakami, A.; Eguchi, K. Mechanisms of Autoantibody Production and the Relationship between Autoantibodies and the Clinical Manifestations in Sjögren's Syndrome. Transl. Res. 2006, 148, 281-288. [CrossRef]

109. Elagib, K.E.; Tengner, P.; Levi, M.; Jonsson, R.; Thompson, K.M.; Natvig, J.B.; Wahren-Herlenius, M. Immunoglobulin Variable Genes and Epitope Recognition of Human Monoclonal Anti-Ro 52-kd in Primary Sjögren's Syndrome. Arthritis Rheum. Off. J. Am. Coll. Rheumatol. 1999, 42, 2471-2481. [CrossRef]

110. Voulgarelis, M.; Tzioufas, A.G. Pathogenetic Mechanisms in the Initiation and Perpetuation of Sjögren's Syndrome. Nat. Rev. Rheumatol. 2010, 6, 529. [CrossRef] [PubMed]

111. Chiang, M.-C.; Chung, C.-R.; Horng, J.-T.; Chen, C.-L. A Bidirectional Study between Rheumatoid Arthritis and Sjogren's Syndrome: A Population-Based Cohort Study in Taiwan. J. Comput. 2019, 30, 232-241.

112. Harrold, L.R.; Shan, Y.; Rebello, S.; Kramer, N.; Connolly, S.E.; Alemao, E.; Kelly, S.; Kremer, J.M.; Rosenstein, E.D. Prevalence of Sjögren's Syndrome Associated with Rheumatoid Arthritis in the USA: An Observational Study from the Corrona Registry. Clin. Rheumatol. 2020, 39, 1899-1905. [CrossRef] [PubMed]

113. Pego-Reigosa, J.M.; Restrepo Vélez, J.; Baldini, C.; Rúa-Figueroa Fernández de Larrinoa, Í. Comorbidities (Excluding Lymphoma) in Sjögren's Syndrome. Rheumatology 2021, 60, 2075-2084. [CrossRef]

114. Giacomelli, R.; Afeltra, A.; Alunno, A.; Baldini, C.; Bartoloni-Bocci, E.; Berardicurti, O.; Carubbi, F.; Cauli, A.; Cervera, R.; Ciccia, F. International Consensus: What Else Can We Do to Improve Diagnosis and Therapeutic Strategies in Patients Affected by Autoimmune Rheumatic Diseases (Rheumatoid Arthritis, Spondyloarthritides, Systemic Sclerosis, Systemic Lupus Erythematosus, Antiphospholipid Syndrome and Sjogren's Syndrome)?: The Unmet Needs and the Clinical Grey Zone in Autoimmune Disease Management. Autoimmun. Rev. 2017, 16, 911-924.

115. Cheng, S.C.H.; Wu, V.W.C.; Kwong, D.L.W.; Ying, M.T.C. Assessment of Post-Radiotherapy Salivary Glands. Br. J. Radiol. 2011, 84, 393-402. [CrossRef]

116. Ship, J.A.; Hu, K. Radiotherapy-Induced Salivary Dysfunction; Elsevier: Amsterdam, The Netherlands, 2004; Volume 31, pp. 29-36.

117. Chambers, M.S.; Garden, A.S.; Kies, M.S.; Martin, J.W. Radiation-induced Xerostomia in Patients with Head and Neck Cancer: Pathogenesis, Impact on Quality of Life, and Management. Head Neck J. Sci. Spec. Head Neck 2004, 26, 796-807. [CrossRef]

118. Grundmann, O.; Mitchell, G.; Limesand, K. Sensitivity of Salivary Glands to Radiation: From Animal Models to Therapies. J. Dent. Res. 2009, 88, 894-903. [CrossRef]

119. Straub, R.H. The Complex Role of Estrogens in Inflammation. Endocr. Rev. 2007, 28, 521-574. [CrossRef]

120. Rubtsov, A.V.; Rubtsova, K.; Kappler, J.W.; Marrack, P. Genetic and Hormonal Factors in Female-Biased Autoimmunity. Autoimmun. Rev. 2010, 9, 494-498. [CrossRef]

121. Legato, M.J.; Bilezikian, J.P. Principles of Gender-Specific Medicine; Gulf Professional Publishing: Houston, TX, USA, 2004; Volume 2, ISBN 0-12-440907-5.

122. Wilder, R.L. Neuroendocrine-Immune System Interactions and Autoimmunity. Annu. Rev. Immunol. 1995, 13, 307-338. [CrossRef] [PubMed]

123. Mostafavi, B.; Akyuz, S.; Jacobsson, M.E.; Nilsen, L.V.; Theander, E.; Jacobsson, L.H. Perinatal Characteristics and Risk of Developing Primary Sjögren's Syndrome: A Case-Control Study. J. Rheumatol. 2005, 32, 665-668.

124. Shelly, S.; Boaz, M.; Orbach, H. Prolactin and Autoimmunity. Autoimmun. Rev. 2012, 11, A465-A470. [CrossRef]

125. Miller, V.M. Why Are Sex and Gender Important to Basic Physiology and Translational and Individualized Medicine? Am. J. Physiol.-Heart Circ. Physiol. 2014. [CrossRef] 
126. Alunno, A.; Carubbi, F.; Bistoni, O.; Caterbi, S.; Bartoloni, E.; Mirabelli, G.; Cannarile, F.; Cipriani, P.; Giacomelli, R.; Gerli, R. T Regulatory and T Helper 17 Cells in Primary Sjögren's Syndrome: Facts and Perspectives. Mediat. Inflamm. 2015, 2015. [CrossRef]

127. Tabarkiewicz, J.; Pogoda, K.; Karczmarczyk, A.; Pozarowski, P.; Giannopoulos, K. The Role of IL-17 and Th17 Lymphocytes in Autoimmune Diseases. Arch. Immunol. Ther. Exp. 2015, 63, 435-449. [CrossRef] [PubMed]

128. Zhang, L.; Zhou, P.; Wei, P.; Cong, X.; Wu, L.; Hua, H. Expression of Interleukin-17 in Primary Sjögren's Syndrome and the Correlation with Disease Severity: A Systematic Review and Meta-analysis. Scand. J. Immunol. 2018, 87, e12649. [CrossRef]

129. Matsui, K.; Sano, H. T Helper 17 Cells in Primary Sjögren's Syndrome. J. Clin. Med. 2017, 6, 65. [CrossRef]

130. Verstappen, G.M.; Corneth, O.B.; Bootsma, H.; Kroese, F.G. Th17 Cells in Primary Sjögren's Syndrome: Pathogenicity and Plasticity. J. Autoimmun. 2018, 87, 16-25. [CrossRef]

131. Lin, X.; Rui, K.; Deng, J.; Tian, J.; Wang, X.; Wang, S.; Ko, K.-H.; Jiao, Z.; Chan, V.S.-F.; Lau, C.S. Th17 Cells Play a Critical Role in the Development of Experimental Sjögren's Syndrome. Ann. Rheum. Dis. 2015, 74, 1302-1310. [CrossRef] [PubMed]

132. Laffont, S.; Rouquié, N.; Azar, P.; Seillet, C.; Plumas, J.; Aspord, C.; Guéry, J.-C. X-Chromosome Complement and Estrogen Receptor Signaling Independently Contribute to the Enhanced TLR7-Mediated IFN- $\alpha$ Production of Plasmacytoid Dendritic Cells from Women. J. Immunol. 2014, 193, 5444-5452. [CrossRef] [PubMed]

133. Kanda, N.; Tamaki, K. Estrogen Enhances Immunoglobulin Production by Human PBMCs. J. Allergy Clin. Immunol. 1999, 103, 282-288. [CrossRef]

134. Sthoeger, Z.; Chiorazzi, N.; Lahita, R. Regulation of the Immune Response by Sex Hormones. I. In Vitro Effects of Estradiol and Testosterone on Pokeweed Mitogen-Induced Human B Cell Differentiation. J. Immunol. 1988, 141, 91-98. [PubMed]

135. Cohen-Solal, J.; Jeganathan, V.; Hill, L.; Kawabata, D.; Pinto-Rodriguez, D.; Grimaldi, C.; Diamond, B. Hormonal Regulation of B-Cell Function and Systemic Lupus Erythematosus. Lupus 2008, 17, 528-532. [CrossRef]

136. Medina, K.L.; Garrett, K.P.; Thompson, L.F.; Rossi, M.I.D.; Payne, K.J.; Kincade, P.W. Identification of Very Early Lymphoid Precursors in Bone Marrow and Their Regulation by Estrogen. Nat. Immunol. 2001, 2, 718-724. [CrossRef]

137. Dinarello, C.A. Interleukin-1, Interleukin-1 Receptors and Interleukin-1 Receptor Antagonist. Int. Rev. Immunol. 1998, 16, 457-499. [CrossRef]

138. Simón, C.; Piquette, G.N.; Frances, A.; Westphal, L.M.; Heinrichs, W.L.; Polan, M.L. Interleukin-1 Type I Receptor Messenger Ribonucleic Acid Expression in Human Endometrium throughout the Menstrual Cycle. Fertil. Steril. 1993, 59, 791-796. [CrossRef]

139. Mandrup-Poulsen, T.; Nerup, J.; Reimers, J.I.; Pociot, F.; Andersen, H.U.; Karlsen, A.; Bjerre, U.; Bergholdt, R. Cytokines and the Endocrine System. I. The Immunoendocrine Network. Eur. J. Endocrinol. 1995, 133, 660-671. [CrossRef]

140. Khan, D.; Ansar Ahmed, S. The Immune System Is a Natural Target for Estrogen Action: Opposing Effects of Estrogen in Two Prototypical Autoimmune Diseases. Front. Immunol. 2016, 6, 635. [CrossRef]

141. Laffont, S.; Seillet, C.; Guéry, J.-C. Estrogen Receptor-Dependent Regulation of Dendritic Cell Development and Function. Front. Immunol. 2017, 8, 108. [CrossRef]

142. Anipindi, V.C.; Bagri, P.; Roth, K.; Dizzell, S.E.; Nguyen, P.V.; Shaler, C.R.; Chu, D.K.; Jiménez-Saiz, R.; Liang, H.; Swift, S. Estradiol Enhances CD4 ${ }^{+}$T-Cell Anti-Viral Immunity by Priming Vaginal DCs to Induce $\mathrm{T}_{\mathrm{h}} 17$ Responses via an IL-1-Dependent Pathway. PLoS Pathog. 2016, 12, e1005589.

143. Lou, Y.; Hu, M.; Wang, Q.; Yuan, M.; Wang, N.; Le, F.; Li, L.; Huang, S.; Wang, L.; Xu, X. Estradiol Suppresses TLR4-Triggered Apoptosis of Decidual Stromal Cells and Drives an Anti-Inflammatory TH2 Shift by Activating SGK1. Int. J. Biol. Sci. 2017, 13, 434. [CrossRef] [PubMed]

144. Beeson, P.B. Age and Sex Associations of 40 Autoimmune Diseases. Am. J. Med. 1994, 96, 457-462. [CrossRef]

145. Ishimaru, N.; Arakaki, R.; Watanabe, M.; Kobayashi, M.; Miyazaki, K.; Hayashi, Y. Development of Autoimmune Exocrinopathy Resembling Sjögren's Syndrome in Estrogen-Deficient Mice of Healthy Background. Am. J. Pathol. 2003, 163, 1481-1490. [CrossRef]

146. Agha-Hosseini, F.; Mirzaii-Dizgah, I.; Mansourian, A.; Khayamzadeh, M. Relationship of Stimulated Saliva 17 $\beta$-Estradiol and Oral Dryness Feeling in Menopause. Maturitas 2009, 62, 197-199. [CrossRef]

147. Forsblad-d'Elia, H.; Carlsten, H.; Labrie, F.; Konttinen, Y.T.; Ohlsson, C. Low Serum Levels of Sex Steroids Are Associated with Disease Characteristics in Primary Sjogren's Syndrome; Supplementation with Dehydroepiandrosterone Restores the Concentrations. J. Clin. Endocrinol. Metab. 2009, 94, 2044-2051. [CrossRef]

148. Manoussakis, M.; Tsinti, M.; Kapsogeorgou, E.; Moutsopoulos, H. The Salivary Gland Epithelial Cells of Patients with Primary Sjögren's Syndrome Manifest Significantly Reduced Responsiveness to 17 $\beta$-Estradiol. J. Autoimmun. 2012, 39, 64-68. [CrossRef]

149. Mostafa, S.; Seamon, V.; Azzarolo, A.M. Influence of Sex Hormones and Genetic Predisposition in Sjögren's Syndrome: A New Clue to the Immunopathogenesis of Dry Eye Disease. Exp. Eye Res. 2012, 96, 88-97. [CrossRef]

150. Saha, S.; Tieng, A.; Pepeljugoski, K.P.; Zandamn-Goddard, G.; Peeva, E. Prolactin, Systemic Lupus Erythematosus, and Autoreactive B Cells: Lessons Learnt from Murine Models. Clin. Rev. Allergy Immunol. 2011, 40, 8-15. [CrossRef]

151. Haga, H.; Rygh, T. The Prevalence of Hyperprolactinemia in Patients with Primary Sjögren's Syndrome. J. Rheumatol. 1999, 26, 1291-1295. [PubMed]

152. Abou-Raya, A.; Abou-Raya, S. Inflammation: A Pivotal Link between Autoimmune Diseases and Atherosclerosis. Autoimmun. Rev. 2006, 5, 331-337.

153. Duan, L.; Rao, X.; Sigdel, K.R. Regulation of Inflammation in Autoimmune Disease. J. Immunol. Res. 2019. [CrossRef] 
154. Racke, M.K.; Bonomo, A.; Scott, D.E.; Cannella, B.; Levine, A.; Raine, C.S.; Shevach, E.M.; Röcken, M. Cytokine-Induced Immune Deviation as a Therapy for Inflammatory Autoimmune Disease. J. Exp. Med. 1994, 180, 1961-1966. [CrossRef]

155. Parashar, K.; Schulte, F.; Hardt, M.; Baker, O.J. Sex-mediated Elevation of the Specialized Pro-resolving Lipid Mediator Levels in a Sjögren's Syndrome Mouse Model. FASEB J. 2020, 34, 7733-7744. [CrossRef] [PubMed]

156. Verma, A.; Schwartz, N.; Cohen, D.J.; Boyan, B.D.; Schwartz, Z. Estrogen Signaling and Estrogen Receptors as Prognostic Indicators in Laryngeal Cancer. Steroids 2019, 152, 108498. [CrossRef]

157. Yoo, H.J.; Sepkovic, D.W.; Bradlow, H.L.; Yu, G.P.; Sirilian, H.V.; Schantz, S.P. Estrogen Metabolism as a Risk Factor for Head and Neck Cancer. Otolaryngol.-Head Neck Surg. 2001, 124, 241-247. [CrossRef]

158. Hashim, D.; Sartori, S.; Vecchia, C.L.; Serraino, D.; Maso, L.D.; Negri, E.; Smith, E.; Levi, F.; Boccia, S.; Cadoni, G. Hormone Factors Play a Favorable Role in Female Head and Neck Cancer Risk. Cancer Med. 2017, 6, 1998-2007. [CrossRef]

159. Gallus, S.; Bosetti, C.; Franceschi, S.; Levi, F.; Negri, E.; La Vecchia, C. Laryngeal Cancer in Women: Tobacco, Alcohol, Nutritional, and Hormonal Factors. Cancer Epidemiol. Prev. Biomark. 2003, 12, 514-517.

160. Langevin, S.M.; Grandis, J.R.; Taioli, E. Female Hormonal and Reproductive Factors and Head and Neck Squamous Cell Carcinoma Risk. Cancer Lett. 2011, 310, 216-221. [CrossRef] [PubMed]

161. Bosetti, C.; Negri, E.; Franceschi, S.; Conti, E.; Levi, F.; Tomei, F.; La Vecchia, C. Risk Factors for Oral and Pharyngeal Cancer in Women: A Study from Italy and Switzerland. Br. J. Cancer 2000, 82, 204-207. [CrossRef] [PubMed]

162. Chaturvedi, A.K.; Anderson, W.F.; Lortet-Tieulent, J.; Curado, M.P.; Ferlay, J.; Franceschi, S.; Rosenberg, P.S.; Bray, F.; Gillison, M.L. Worldwide Trends in Incidence Rates for Oral Cavity and Oropharyngeal Cancers. J. Clin. Oncol. 2013, 31, 4550. [CrossRef]

163. Dumitrescu, R.G.; Shields, P.G. The Etiology of Alcohol-Induced Breast Cancer. Alcohol 2005, 35, 213-225. [CrossRef] [PubMed]

164. Castro, G.D.; Castro, J.A. Alcohol Drinking and Mammary Cancer: Pathogenesis and Potential Dietary Preventive Alternatives. World J. Clin. Oncol. 2014, 5, 713. [CrossRef]

165. Suzuki, R.; Ye, W.; Rylander-Rudqvist, T.; Saji, S.; Colditz, G.A.; Wolk, A. Alcohol and Postmenopausal Breast Cancer Risk Defined by Estrogen and Progesterone Receptor Status: A Prospective Cohort Study. J. Natl. Cancer Inst. 2005, 97, 1601-1608. [CrossRef]

166. Purohit, V. Can Alcohol Promote Aromatization of Androgens to Estrogens? A Review. Alcohol 2000, 22, 123-127. [CrossRef]

167. Schuller, D.E.; Abou-Issa, H.; Parrish, R. Estrogen and Progesterone Receptors in Head and Neck Cancer. Arch. Otolaryngol. 1984, 110, 725-727. [CrossRef]

168. Egloff, A.M.; Rothstein, M.E.; Seethala, R.; Siegfried, J.M.; Grandis, J.R.; Stabile, L.P. Cross-Talk between Estrogen Receptor and Epidermal Growth Factor Receptor in Head and Neck Squamous Cell Carcinoma. Clin. Cancer Res. 2009, 15, 6529-6540. [CrossRef]

169. Chang, Y.-L.; Hsu, Y.-K.; Wu, T.-F.; Huang, C.-M.; Liou, L.-Y.; Chiu, Y.-W.; Hsiao, Y.-H.; Luo, F.-J.; Yuan, T.-C. Regulation of Estrogen Receptor a Function in Oral Squamous Cell Carcinoma Cells by FAK Signaling. Endocr. Relat. Cancer 2014, 21, 555-565. [CrossRef]

170. Harris, S.L.; Kimple, R.J.; Hayes, D.N.; Couch, M.E.; Rosenman, J.G. Never-smokers, Never-drinkers: Unique Clinical Subgroup of Young Patients with Head and Neck Squamous Cell Cancers. Head Neck J. Sci. Spec. Head Neck 2010, 32, 499-503. [CrossRef]

171. Rothenberger, N.J.; Somasundaram, A.; Stabile, L.P. The Role of the Estrogen Pathway in the Tumor Microenvironment. Int. J. Mol. Sci. 2018, 19, 611. [CrossRef]

172. Korniluk, A.; Koper, O.; Kemona, H.; Dymicka-Piekarska, V. From Inflammation to Cancer. Ir. J. Med. Sci. 2017, 186, 57-62. [CrossRef]

173. Lawrence, T. Inflammation and Cancer: A Failure of Resolution? Trends Pharmacol. Sci. 2007, 28, 162-165. [CrossRef] [PubMed]

174. Munn, L.L. Cancer and Inflammation. Wiley Interdiscip. Rev. Syst. Biol. Med. 2017, 9, e1370. [CrossRef]

175. Chanmee, T.; Ontong, P.; Konno, K.; Itano, N. Tumor-Associated Macrophages as Major Players in the Tumor Microenvironment. Cancers 2014, 6, 1670-1690. [CrossRef]

176. Malfitano, A.M.; Pisanti, S.; Napolitano, F.; Di Somma, S.; Martinelli, R.; Portella, G. Tumor-Associated Macrophage Status in Cancer Treatment. Cancers 2020, 12, 1987. [CrossRef] [PubMed]

177. Ye, Y.; Scheff, N.N.; Bernabé, D.; Salvo, E.; Ono, K.; Liu, C.; Veeramachaneni, R.; Viet, C.T.; Viet, D.T.; Dolan, J.C. Anti-Cancer and Analgesic Effects of Resolvin D2 in Oral Squamous Cell Carcinoma. Neuropharmacology 2018, 139, 182-193. [CrossRef]

178. Contaldo, M.; Boccellino, M.; Zannini, G.; Romano, A.; Sciarra, A.; Sacco, A.; Settembre, G.; Coppola, M.; Di Carlo, A.; D’Angelo, L. Sex Hormones and Inflammation Role in Oral Cancer Progression: A Molecular and Biological Point of View. J. Oncol. 2020, 2020. [CrossRef] [PubMed]

179. Ghisletti, S.; Meda, C.; Maggi, A.; Vegeto, E. 17ß-Estradiol Inhibits Inflammatory Gene Expression by Controlling NF-KB Intracellular Localization. Mol. Cell. Biol. 2005, 25, 2957-2968. [CrossRef]

180. Reed, J.L.; Dimayuga, F.O.; Davies, L.M.; Keller, J.N.; Bruce-Keller, A.J. Estrogen Increases Proteasome Activity in Murine Microglial Cells. Neurosci. Lett. 2004, 367, 60-65. [CrossRef]

181. Rettew, J.A.; McCall IV, S.H.; Marriott, I. GPR30/GPER-1 Mediates Rapid Decreases in TLR4 Expression on Murine Macrophages. Mol. Cell. Endocrinol. 2010, 328, 87-92. [CrossRef]

182. Shatalova, E.G.; Klein-Szanto, A.J.; Devarajan, K.; Cukierman, E.; Clapper, M.L. Estrogen and Cytochrome P450 1B1 Contribute to Both Early-and Late-Stage Head and Neck Carcinogenesis. Cancer Prev. Res. 2011, 4, 107-115. [CrossRef]

183. Chung, S.-H.; Franceschi, S.; Lambert, P.F. Estrogen and ER $\alpha$ : Culprits in Cervical Cancer? Trends Endocrinol. Metab. 2010, 21, 504-511. [CrossRef] 
184. Tomasovic-Loncaric, C.; Fucic, A.; Andabak, A.; Andabak, M.; Ceppi, M.; Bruzzone, M.; Vrdoljak, D.; Vucicevic-Boras, V. Androgen Receptor as a Biomarker of Oral Squamous Cell Carcinoma Progression Risk. Anticancer Res. 2019, 39, 4285-4289. [CrossRef]

185. Batelja-Vuletic, L.; Tomasovic-Loncaric, C.; Ceppi, M.; Bruzzone, M.; Fucic, A.; Krstanac, K.; Boras Vucicevic, V. Comparison of Androgen Receptor, Vegf, Hif-1, Ki67 and Mmp9 Expression between Non-Metastatic and Metastatic Stages in Stromal and Tumor Cells of Oral Squamous Cell Carcinoma. Life 2021, 11, 336. [CrossRef]

186. Bonomi, M.; Patsias, A.; Posner, M.; Sikora, A. The Role of Inflammation in Head and Neck Cancer. Inflamm. Cancer 2014, 107-127.

187. Huang, C.-F.; Chen, L.; Li, Y.-C.; Wu, L.; Yu, G.-T.; Zhang, W.-F.; Sun, Z.-J. NLRP3 Inflammasome Activation Promotes Inflammation-Induced Carcinogenesis in Head and Neck Squamous Cell Carcinoma. J. Exp. Clin. Cancer Res. 2017, $36,1-13$. [CrossRef]

188. Farah, C.S.; Shearston, K.; Nguyen, A.P.; Kujan, O. Oral carcinogenesis and malignant transformation. In Premalignant Conditions of the Oral Cavity; Springer: Berlin/Heidelberg, Germany, 2019; pp. 27-66.

189. Slama, B. Potentially Malignant Disorders of the Oral Mucosa: Terminology and Classification. Rev. Stomatol. Chir. Maxillo-Faciale 2010, 111, 208-212.

190. Nasry, W.H.S.; Rodriguez-Lecompte, J.C.; Martin, C.K. Role of COX-2/PGE2 Mediated Inflammation in Oral Squamous Cell Carcinoma. Cancers 2018, 10, 348. [CrossRef]

191. Chapkin, R.S.; Kim, W.; Lupton, J.R.; McMurray, D.N. Dietary Docosahexaenoic and Eicosapentaenoic Acid: Emerging Mediators of Inflammation. Prostaglandins Leukot. Essent. Fat. Acids 2009, 81, 187-191. [CrossRef]

192. Kwon, Y. Immuno-Resolving Ability of Resolvins, Protectins, and Maresins Derived from Omega-3 Fatty Acids in Metabolic Syndrome. Mol. Nutr. Food Res. 2020, 64, 1900824. [CrossRef] [PubMed]

193. Prevete, N.; Liotti, F.; Amoresano, A.; Pucci, P.; de Paulis, A.; Melillo, R.M. New Perspectives in Cancer: Modulation of Lipid Metabolism and Inflammation Resolution. Pharmacol. Res. 2018, 128, 80-87. [CrossRef] [PubMed]

194. Luo, S.-D.; Chen, W.-C.; Wu, C.-N.; Yang, Y.-H.; Li, S.-H.; Fang, F.-M.; Huang, T.-L.; Wang, Y.-M.; Chiu, T.-J.; Wu, S.-C. Low-Dose Aspirin Use Significantly Improves the Survival of Late-Stage NPC: A Propensity Score-Matched Cohort Study in Taiwan. Cancers 2020, 12, 1551. [CrossRef]

195. Canny, G.; Lessey, B. The Role of Lipoxin A 4 in Endometrial Biology and Endometriosis. Mucosal Immunol. 2013, 6, 439-450. [CrossRef]

196. Hallisey, V.M.; Kipper, F.C.; Moore, J.; Gartung, A.; Bielenberg, D.R.; Petrik, J.; Lawler, J.; Panigrahy, D.; Serhan, C.N. Pro-Resolving Lipid Mediators and Anti-Angiogenic Therapy Exhibit Synergistic Anti-Tumor Activity via Resolvin Receptor Activation. FASEB J. 2020, 34, 1. [CrossRef]

197. Yang, P.; Chen, S.; Zhong, G.; Wang, Y.; Kong, W.; Wang, Y. ResolvinD1 Attenuates High-Mobility Group Box 1-Induced Epithelial-to-Mesenchymal Transition in Nasopharyngeal Carcinoma Cells. Exp. Biol. Med. 2019, 244, 1608-1618. [CrossRef]

198. Van Cauwenberge, P.; Watelet, J.-B. Epidemiology of Chronic Rhinosinusitis. Thorax 2000, 55, S20-S21. [CrossRef] [PubMed]

199. Hamilos, D.L. Chronic Rhinosinusitis: Epidemiology and Medical Management. J. Allergy Clin. Immunol. 2011, $128,693-707$. [CrossRef]

200. Ryu, G.; Kim, D.W. Th2 Inflammatory Responses in the Development of Nasal Polyps and Chronic Rhinosinusitis. Curr. Opin. Allergy Clin. Immunol. 2020, 20, 1-8. [CrossRef]

201. Ference, E.H.; Tan, B.K.; Hulse, K.E.; Chandra, R.K.; Smith, S.B.; Kern, R.C.; Conley, D.B.; Smith, S.S. Commentary on Gender Differences in Prevalence, Treatment, and Quality of Life of Patients with Chronic Rhinosinusitis. Allergy Rhinol. 2015, 6, ar-2015. [CrossRef]

202. Coksuer, H.; Ozcura, F.; Oghan, F.; Haliloglu, B.; Coksuer, C. Effects of Estradiol-Drospirenone on Ocular and Nasal Functions in Postmenopausal Women. Climacteric 2011, 14, 482-487. [CrossRef]

203. Haeggström, A.; Östberg, B.; Stjerna, P.; Graf, P.; Hallén, H. Nasal Mucosal Swelling and Reactivity during a Menstrual Cycle. ORL 2000, 62, 39-42. [CrossRef]

204. Busaba, N.Y.; Sin, H.-J.; Salman, S.D. Impact of Gender on Clinical Presentation of Chronic Rhinosinusitis with and without Polyposis. J. Laryngol. Otol. 2008, 122, 1180-1184. [CrossRef]

205. World Health Organization. Addressing the Rising Prevalence of Hearing Loss; World Health Organization: Geneva, Switzerland, 2018.

206. Bowl, M.R.; Dawson, S.J. Age-Related Hearing Loss. Cold Spring Harb. Perspect. Med. 2019, 9, a033217. [CrossRef]

207. Dirix, P.; Nuyts, S.; Bogaert, W. Radiation-Induced Xerostomia in Patients with Head and Neck Cancer: A Literature Review. Cancer 2006, 107, 2525-2534. [CrossRef] [PubMed]

208. Aziz, K.E.; Montanaro, A.; McCluskey, P.J.; Wakefield, D. Sjogren's Syndrome: Review with Recent Insights into Immunopathogenesis. Aust. N. Z. J. Med. 1992, 22, 671-678. [CrossRef]

209. Henkin, R.; Talal, N.; Larson, A.; Mattern, C. Abnormalities of Taste and Smell in Sjogren's Syndrome. Ann. Intern. Med. 1972, 76, 375-383. [CrossRef] [PubMed]

210. Galarza-Delgado, D.A.; Gonzalez, M.J.V.; Torres, J.R.; Soto-Galindo, G.A.; Flores, L.M.; González, J.L.T. Early Hearing Loss Detection in Rheumatoid Arthritis and Primary Sjögren Syndrome Using Extended High Frequency Audiometry. Clin. Rheumatol. 2018, 37, 367-373. [CrossRef] 
211. Huerta-Rosario, A.; Molina, R.A.; Ventura-Chilón, J.J.; Terreros, A.; Alva-Diaz, C.; Pacheco-Barrios, K.; Sánchez, R.R.; Quispe, N.M. Chronic Meningitis as an Initial Presentation of Sjögren Syndrome. Rev. Colomb. Reumatol. 2020, 27, 166-170.

212. Jeong, J.; Lim, H.; Lee, K.; Hong, C.E.; Choi, H.S. High Risk of Sudden Sensorineural Hearing Loss in Several Autoimmune Diseases According to a Population-Based National Sample Cohort Study. Audiol. Neurotol. 2019, 24, 224-230. [CrossRef]

213. Tumiati, B.; Casoli, P.; Parmeggiani, A. Hearing Loss in the Sjogren Syndrome. Ann. Intern. Med. 1997, 126, 450-453. [CrossRef] [PubMed]

214. Graf, S.; Kirschstein, L.; Knopf, A.; Mansour, N.; Jeleff-Wölfler, O.; Buchberger, A.; Hofauer, B. Systematic Evaluation of Laryngeal Impairment in Sjögren's Syndrome. Eur. Arch. Oto-Rhino-Laryngol. 2021, 1-8. [CrossRef]

215. Heller, A.; Tanner, K.; Roy, N.; Nissen, S.L.; Merrill, R.M.; Miller, K.L.; Houtz, D.R.; Ellerston, J.; Kendall, K. Voice, Speech, and Laryngeal Features of Primary Sjögren's Syndrome. Ann. Otol. Rhinol. Laryngol. 2014, 123, 778-785. [CrossRef]

216. Brandt, J.E.; Priori, R.; Valesini, G.; Fairweather, D. Sex Differences in Sjögren's Syndrome: A Comprehensive Review of Immune Mechanisms. Biol. Sex Differ. 2015, 6, 1-13. [CrossRef] [PubMed]

217. Mathews, P.M.; Hahn, S.; Hessen, M.; Kim, J.; Grader-Beck, T.; Birnbaum, J.; Baer, A.N.; Akpek, E.K. Ocular Complications of Primary Sjögren Syndrome in Men. Am. J. Ophthalmol. 2015, 160, 447-452. [CrossRef] [PubMed]

218. Tellefsen, S.; Morthen, M.K.; Richards, S.M.; Lieberman, S.M.; Darabad, R.R.; Kam, W.R.; Sullivan, D.A. Sex Effects on Gene Expression in Lacrimal Glands of Mouse Models of Sjögren Syndrome. Investig. Ophthalmol. Vis. Sci. 2018, 59, 5599-5614. [CrossRef]

219. Yang, L.; Wei, W.; He, X.; Xie, Y.; Kamal, M.A.; Li, J. Influence of Hormones on Sjögren's Syndrome. Curr. Pharm. Des. 2018, 24, 4167-4176. [CrossRef]

220. McCoy, S.S.; Sampene, E.; Baer, A.N. Association of Sjögren's Syndrome With Reduced Lifetime Sex Hormone Exposure: A Case-Control Study. Arthritis Care Res. 2020, 72, 1315-1322. [CrossRef]

221. Cui, Y.; Xia, L.; Zhao, Q.; Chen, S.; Gu, Z. Anxiety and Depression in Primary Sjögren's Syndrome: A Cross-Sectional Study. BMC Psychiatry 2018, 18, 131. [CrossRef]

222. Koçer, B.; Tezcan, M.E.; Batur, H.Z.; Haznedaroğlu, Ş.; Göker, B.; İrkeç, C.; Çetinkaya, R. Cognition, Depression, Fatigue, and Quality of Life in Primary Sjögren's Syndrome: Correlations. Brain Behav. 2016, 6, e00586. [CrossRef]

223. Liu, Z.; Dong, Z.; Liang, X.; Liu, J.; Xuan, L.; Wang, J.; Zhang, G.; Hao, W. Health-Related Quality of Life and Psychological Status of Women with Primary Sjögren's Syndrome: A Cross-Sectional Study of 304 Chinese Patients. Medicine 2017, 96, e9208. [CrossRef] [PubMed]

224. Miyamoto, S.T.; Valim, V.; Fisher, B.A. Health-Related Quality of Life and Costs in Sjögren's Syndrome. Rheumatology 2021, 60, 2588-2601. [CrossRef]

225. Hammitt, K.M.; Naegeli, A.N.; van den Broek, R.W.; Birt, J.A. Patient Burden of Sjögren's: A Comprehensive Literature Review Revealing the Range and Heterogeneity of Measures Used in Assessments of Severity. RMD Open 2017, 3, e000443. [CrossRef]

226. Fox, R.I.; Howell, F.V.; Bone, R.C.; Michelson, P.E. Primary Sjogren Syndrome: Clinical and Immunopathologic Features; Elsevier: Amsterdam, The Netherlands, 1984; Volume 14, pp. 77-105.

227. Azuma, M.; Motegi, K.; Aota, K.; Hayashi, Y.; Sato, M. Role of Cytokines in the Destruction of Acinar Structure in Sjogren's Syndrome Salivary Glands. Lab. Investig. 1997, 77, 269-280.

228. Baker, O.J. Proinflammatory Cytokines Tumor Necrosis Factor-Alpha and Interferon-Gamma Alter Tight Junction Structure and Function in the Rat Parotid Gland Par-C10 Cell Line. Am. J. Physiol. Cell Physiol. 2008, 295, 1191-1201. [CrossRef] [PubMed]

229. Roescher, N.; Tak, P.P.; Illei, G.G. Cytokines in Sjögren's Syndrome. Oral Dis. 2009, 15, 519-526. [CrossRef]

230. Jonsson, R.; Vogelsang, P.; Volchenkov, R.; Espinosa, A.; Wahren-Herlenius, M.; Appel, S. The Complexity of Sjögren's Syndrome: Novel Aspects on Pathogenesis. Immunol. Lett. 2011, 141, 1-9. [CrossRef]

231. Ambrosi, A.; Wahren-Herlenius, M. Update on the Immunobiology of Sjögren's Syndrome. Curr. Opin. Rheumatol. 2015, 27, 468-475. [CrossRef] [PubMed]

232. Michalski, J.P.; Daniels, T.E.; Talal, N.; Grey, H.M. Beta2 Microglobulin and Lymphocytic Infiltration in Sjögren's Syndrome. N. Engl. J. Med. 1975, 293, 1228-1231. [CrossRef]

233. Nikolov, N.P.; Illei, G.G. Pathogenesis of Sjögren's Syndrome. Curr. Opin. Rheumatol. 2009, 21, 465. [CrossRef]

234. Recchiuti, A.; Isopi, E.; Romano, M.; Mattoscio, D. Roles of Specialized Pro-Resolving Lipid Mediators in Autophagy and Inflammation. IJMS 2020, 21, 6637. [CrossRef]

235. Dean, S.; Wang, C.-S.; Nam, K.; Maruyama, C.L.; Trump, B.G.; Baker, O.J. Aspirin Triggered Resolvin D1 Reduces Inflammation and Restores Saliva Secretion in a Sjögren's Syndrome Mouse Model. Rheumatology 2019, 58, 1285-1292. [CrossRef]

236. Easley, J.T.; Maruyama, C.L.; Wang, C.; Baker, O.J. AT-RvD1 Combined with DEX Is Highly Effective in Treating TNF- $\alpha$-mediated Disruption of the Salivary Gland Epithelium. Physiol. Rep. 2016, 4, e12990. [CrossRef]

237. Sommakia, S.; Baker, O.J. Regulation of Inflammation by Lipid Mediators in Oral Diseases. Oral Dis. 2017, 23, 576-597. [CrossRef] [PubMed]

238. Odusanwo, O.; Chinthamani, S.; McCall, A.; Duffey, M.E.; Baker, O.J. Resolvin D1 Prevents TNF- $\alpha$-Mediated Disruption of Salivary Epithelial Formation. Am. J. Physiol.-Cell Physiol. 2012, 302, C1331-C1345. [CrossRef]

239. Cook, M.B.; McGlynn, K.A.; Devesa, S.S.; Freedman, N.D.; Anderson, W.F. Sex Disparities in Cancer Mortality and Survival. Cancer Epidemiol. Prev. Biomark. 2011, 20, 1629-1637. [CrossRef] [PubMed]

240. Zhu, Y.; Shao, X.; Wang, X.; Liu, L.; Liang, H. Sex Disparities in Cancer. Cancer Lett. 2019, 466, 35-38. [CrossRef] 
241. Chen, Y.-J.; Chang, J.T.-C.; Liao, C.-T.; Wang, H.-M.; Yen, T.-C.; Chiu, C.-C.; Lu, Y.-C.; Li, H.-F.; Cheng, A.-J. Head and Neck Cancer in the Betel Quid Chewing Area: Recent Advances in Molecular Carcinogenesis. Cancer Sci. 2008, 99, 1507-1514. [CrossRef]

242. Vigneswaran, N.; Williams, M.D. Epidemiologic Trends in Head and Neck Cancer and Aids in Diagnosis. Oral Maxillofac. Surg. Clin. N. Am. 2014, 26, 123-141. [CrossRef] [PubMed]

243. Simard, E.P.; Torre, L.A.; Jemal, A. International Trends in Head and Neck Cancer Incidence Rates: Differences by Country, Sex and Anatomic Site. Oral Oncol. 2014, 50, 387-403. [CrossRef] [PubMed]

244. Taberna, M.; Inglehart, R.C.; Pickard, R.K.L.; Fakhry, C.; Agrawal, A.; Katz, M.L.; Gillison, M.L. Significant Changes in Sexual Behavior after a Diagnosis of Human Papillomavirus-Positive and Human Papillomavirus-Negative Oral Cancer. Cancer 2017, 123, 1156-1165. [CrossRef] [PubMed] 